\title{
AÇÕES AFIRMATIVAS: O EXAME DA RESERVA DE VAGAS PARA NEGROS E PARDOS EM CONCURSOS PÚBLICOS À LUZ DOS PRECEITOS CONSTITUCIONAIS ${ }^{\star}$
}

\author{
Dayane Duarte Claudino** \\ Ana Lúcia Brunetta Cardoso****
}

\section{RESUMO}

A reserva de vagas em concursos públicos conferida a negros e pardos é tema controverso que permeia a sociedade. 0 povo brasileiro é formado por variada composição étnica, entretanto, devido a fatores históricos, gerou-se um largo abismo socioeconômico entre brancos, negros e pardos. Frente a esta realidade, viu-se a necessidade da criação de políticas públicas de inclusão, que objetivam, dentre outras diretrizes, reduzir tais desigualdades sociais. Em contraponto a estas medidas, surgem questionamentos relativos à inconstitucionalidade das cotas étnico-raciais em concursos públicos, sob o argumento de que tal prerrogativa colide diretamente com um dos pilares constitucionais mais relevantes de nosso ordenamento jurídico pátrio: o princípio da igualdade. Diante desta polarização de interesses em um país miscigenado, faz-se necessária uma profunda análise sobre o tema. Se por um lado temos tutelado o respeito ao princípio da igualdade, por outro lado, esbarramos em um país que carrega profundas cicatrizes de um passado escravocrata, que reflete suas consequências na formação da sociedade contemporânea. Deste modo,

* Artigo apresentado ao Curso de Bacharelado em Direito do Centro Universitário Metodista - IPA, como requisito parcial para obtenção do Grau de Bacharel em Direito.

** Graduanda do Curso de Bacharelado em Direito do Centro Universitário Metodista - IPA.

*** Orientadora do artigo, Mestre em Direito e professora do Curso de Bacharelado em Direito do Centro Universitário Metodista - IPA. 
o tema será abordado com vistas a investigar a constitucionalidade das cotas étnico-raciais em concursos públicos. Para a produção do presente artigo, será utilizada pesquisa doutrinária e análise de caso jurídico, bem como a investigação contextual histórica em que se deu a escravidão no Brasil, seus reflexos na construção do cenário social atual, e os resultados alcançados com a promulgação da Lei 12.990 de 2014. Tal metodologia será adotada com a finalidade de solver questões essenciais levantadas pela sociedade em relação ao tema em epígrafe.

Palavras-chave: Cotas étnico-raciais. Princípio da Igualdade. Reflexos da Escravidão. Desigualdades sociais.

\section{AFFIRMATIVE ACTIONS:THE EXAMINATION OF THE RESERVE OF VACANCIES FOR BLACKS AND BROWNS IN PUBLIC CONTESTS IN THE LIGHT OF THE CONSTITUTIONAL PRECEPTS}

\section{ABSTRACT}

The vacancy reservation in public contests for blacks and browns it is a controversial subject that it's part of the society. The Brazilian people are formed by a varied ethnic composition. However, due to historical factors, a large socioeconomic abyss was generated between whites, blacks and browns. Against this reality, saw himself a necessity of creation of public politics of inclusion, that aims, among others guidelines, to reduce those social inequalities. On the other hand, emerge questions about the unconstitutionality of the ethnic-racial quotas in public contests, arguing that this prerogative directly conflicts with one of the most relevant constitutional pillars of our legal system: the principle of equality. Against this polarization of interests in a mixed country, it is made necessary a deep analyze about the subject. If on one hand we have protected the respect for the equality principle, on the other hand, we bump into a country that carries deep scars of a slavery past, what reflects its consequences on the contemporary society formation. This way, the subject will be approached with views to investigate the ethnic-racial quotas constitutionality. For the production of this article, it will be used a doctrinal and legal research, as well as the investigation of the historic context in what happened the slavery in Brazil, its reflections on the construction of the actual social scenario and the results achieved with the promulgation of the Law 12.990 from 2014. Such methodology will be adopted with the finality of solve essential questions raised by the society regarding the above subject.

Keywords: ethnic-racial quotas; equality principle; slavery reflections; social inequality. 


\section{INTRODUÇÃO}

Há tempos a humanidade busca por igualdade. Sua obtenção, no contexto atual, advém de revoluções e lutas sociais. Em verdade podemos afirmar que essa busca ainda continua. Neste sentido, o presente artigo visa investigar a constitucionalidade da reserva de vagas para negros e pardos em concursos públicos, uma vez que tal política pública de inclusão levanta intensas discussões envolvendo o princípio constitucional da Igualdade.

0 exame do tema em questão tem como objetivo específico a análise do contexto social em que vive a população negra em nosso país, os fatores históricos que contribuíram para a formação da sociedade brasileira e sua relação com a existência de desigualdades sociais. Após identificadas tais singularidades, será averiguada a consonância da política pública de cotas étnico-raciais em concursos públicos com os demais preceitos constitucionais vigentes, bem como a verificação dos resultados das medidas propostas pela Lei Federal no 12.990/2014, identificando seus efeitos como política pública de inclusão.

No que se refere a formação da sociedade brasileira, não podemos analisá-la devidamente sem falarmos em história do Brasil. Da mesma forma, não podemos falar em história do Brasil sem lembrarmos os horrores vividos pelos negros durante o período escravista. Entender o passado, e como se deram as transformações da sociedade brasileira, considerando seus aspectos históricos e legais, é de fundamental importância para entendermos o presente, e a atual posição socioeconômica alcançada por negros e pardos.

Nosso país é considerado relativamente jovem, as primeiras caravelas portuguesas aportaram em solo brasileiro no ano de 1500 (MESGRAVIS, 2015, p. 12). Entretanto, apenas em 1538 foram trazidos os primeiros africanos escravizados ao Brasil (RIBEIR0, 1995, p. 161). Doravante, foram 350 anos maculados pela escravidão. Este período tenebroso da história brasileira 
findou em 13 de maio de 1888, ano da assinatura da Lei Imperial no 3.353, também conhecida por Lei Áurea, que extinguiu a escravidão, e declarou como livres todos os seres humanos que viviam sob essa condição (BRASIL, 1888).

Podemos afirmar, portanto, que em termos históricos a escravidão é um passado muito recente. De 1888, ano da abolição, até 2018, ano da produção do presente artigo, passaram-se apenas 130 anos, período em que a população negra é livre. Em um país com atuais 518 anos de existência foram ao todo 350 de escravidão, o que representa cerca de três quartos de nossa história. Naturalmente, este aspecto causou um enorme impacto na formação da sociedade brasileira contemporânea.

Após anos vivendo como cativos, os ex-escravos encontraram muita resistência para ingressar no mercado de trabalho, restando aos negros as piores ocupações. Além da exclusão em âmbito trabalhista, sofreram também exclusão geográfica, passando a viver em regiões periféricas (MATTOS, 2007, p. 187).

Com o advento da Constituição de 1988, os olhos do poder legislativo voltaram-se para os direitos e garantias fundamentais. Ademais, a carta magna estabeleceu ainda normas programáticas, metas, e objetivos a serem alcançados pelo Estado. Neste contexto, e na esteira de movimentos sociais, surgiram as políticas afirmativas, dentre elas o sistema de cotas raciais. Tais medidas consistem em métodos potencialmente capazes de mitigar os prejuízos históricos advindos da escravidão no Brasil. (FONSECA, 2009, p. 11)

Surgiram, então, inúmeras oposições a esta espécie de "justiça compensatória". Dentre os mais diversos argumentos estão aqueles relativos a violação ao princípio da igualdade, um dos pilares de nosso ordenamento jurídico pátrio. Sua previsão é referenciada no caput do artigo 50 da Constituição Federal de 1988, com a seguinte redação: 
Todos são iguais perante a lei, sem distinção de qualquer natureza, garantindo-se aos brasileiros e aos estrangeiros residentes no País a inviolabilidade do direito à vida, à liberdade, à igualdade, à segurança e à propriedade, nos termos seguintes. (BRASIL, 1988, paginação irregular)

Desta forma conclui-se que o referido princípio se consolidou como um dos fundamentos básicos de todo o arcabouço legal brasileiro.

Paira, entretanto, certo subjetivismo no significado do termo "igualdade", sendo esse interpretado de variadas maneiras pelos membros da sociedade, juristas e doutrinadores. 0 que nos torna iguais? Essa pergunta tem muitas respostas.

Portanto, o presente artigo busca a resolução do seguinte problema: por que a reserva de vagas para negros e pardos em concursos públicos está em consonância com o princípio constitucional da igualdade?

A matéria é atual, embora pouco abordada, ou abordada superficialmente pelas instituições de ensino, mostra-se de extrema relevância uma vez que trata da efetivação de direitos fundamentais, da busca pela essência do ideal de justiça e igualdade, e do fenômeno da exclusão e inclusão social dos negros em nosso país. Ademais, vale salientar que, apesar de sua importância, ainda há falta de informações sobre o tema, tornando-o obscuro para grande parte da população, que acaba, desta forma, por interpretá-lo de maneira rasa e, muitas vezes, poluída por ideologias políticas.

0 interesse pelo assunto surgiu da reflexão sobre as desigualdades sociais, tão latentes em nosso país, bem como da vontade de elucidar aos leitores do presente artigo acerca da história afro-brasileira e da importância das políticas afirmativas para o alcance da igualdade real e promoção da dignidade da pessoa humana. 


\section{ESCRAVIDÃO: UMA MÁCULA EM NOSSA HISTÓRIA}

\subsection{BRASIL COLÔNIA}

Uma análise aprofundada da construção da sociedade brasileira exige a investigação de seu passado. Fechar os olhos a fatos irrefutáveis que marcaram a formação de nosso povo é negar nossa própria história. Neste sentido, "Pensar a sociedade brasileira contemporânea exige uma reflexão sobre sua herança colonial [...]" (VITA, 2004, p. 12). Logo, é correto afirmar que o referido período foi determinante para a estruturação e composição da pirâmide social brasileira.

Por séculos o Brasil foi explorado como colônia de Portugal. Este tipo de dominação implicou em consequências políticas, administrativas e econômicas:

O termo colônia designa a posição jurídica de um país que é posse de outro (a metrópole), que, por sua vez, tem toda a autoridade sobre ele do ponto de vista político, administrativo, e, sobretudo, econômico - o que significa a exploração das riquezas da colônia em benefício da metrópole. (MESGRAVIS, 2015, p. 9)

Logo, o principal objetivo do colonialismo era a acumulação de capital, que se dava pela exploração e transferência da renda gerada na colônia para a metrópole. Portanto, eram produzidas na colônia as mercadorias de maior demanda da sociedade europeia. O plantio de açúcar, algodão e tabaco movimentava o mercado brasileiro (MATTOS; 2007, p. 64). Desta forma, a indústria mercantil exigia alta produção a baixo custo, impossibilitando a utilização de trabalho livre que, neste caso, demandaria o pagamento de salários e o estabelecimento por conta própria do trabalhador (VITA, 2004, p. 13). "A propriedade escravista (para produção de açúcar antes, e do café depois) era, portanto, a característica 
principal da agricultura brasileira do período colonial e durante todo o século XIX”. (PINSKY ,2010, p. 26). Nesse sentido, "O escravo negro foi, em algumas regiões, a mão de obra exclusiva desde os primórdios da colônia. Durante todo esse período, a história do trabalho é, sobretudo, a história do escravo" (COSTA, 1998, p.14). Este tipo de exploração vigorou por séculos no Brasil, a dependência da mão de obra escrava corroborou para que o país fosse um dos últimos a abolir a escravidão:

A mão de obra utilizada durante todo o período colonial e imperial foi a escrava, primeiro a indígena e, depois, a negra, mas a escravidão não foi uma prática exclusiva do Brasil, pois ela já existia desde a Antiguidade, entretanto nosso país foi um dos últimos a aboli-la. (MARTINS; MACHADO, 2004, p. 17)

Podemos afirmar, portanto, que os escravos foram peça fundamental na construção do mercado econômico brasileiro durante a maior parte de nossa história.

\subsection{A ESCRAVIDÃO INDÍGENA}

Ao aportar as caravelas em solo brasileiro, os portugueses se deparam com os povos indígenas. Logo trataram de explorar a mão de obra aqui existente. "Antes de chegar à escravidão negra, a História do Brasil, já em seu primeiro século, registra a utilização do trabalho do índio" (PINSKY, 2010, p.17). Os nativos atendiam às necessidades dos portugueses e vendiam sua força de trabalho em troca de quinquilharias. Essa relação funcionou bem, porém, satisfeita a curiosidade destes acerca dos produtos europeus, passaram a se desinteressar pelas trocas, e o escambo não mais resolvia as demandas portuguesas. (PINSKY, 2010, p.17).

A submissão dos índios se deu de duas maneiras diversas: uma delas foi pela captura para o trabalho compulsório, e a outra 
foi por meio dos jesuítas nas missões. Neste tipo de submissão os índios não eram escravizados, porém trabalhavam na terra, eram aldeados, e educados. (MARTINS; MACHADO, 2004, p. 17) Ademais, vale salientar que os jesuítas conferiram proteção a esta população, e esforçaram-se para transforma-los, por meio do ensino, em "bons cristãos" (FAUSTO, 2006, p. 23). Eles estabeleceram limitações ao trabalho escravo dos índios em nome de Deus, todavia, em nome de quem acataram a escravidão negra? (PINSKY, 2010, p. 22).

Lembremos também o tratamento dado ao negro na legislação. 0 contraste com os indígenas é nesse aspecto evidente. Estes contavam com leis protetoras contra escravidão, ainda que fossem pouco aplicadas e contivessem muitas ressalvas. 0 negro escravizado não tinha direitos, mesmo porque era considerado juridicamente uma coisa. (FAUSTO, 2006, p. 26)

Ou seja, enquanto o negro era reles pertence, um elemento sem alma ou mera mercadoria, o índio era visto como um ser dotado de consciência, porém não catequizado.

\subsubsection{Por que o negro?}

Vários foram os fatores que determinaram a substituição do trabalho do índio pelo trabalho do negro africano. Dentre eles podemos destacar a cultura de subsistência indígena, que se mostrava incompatível com o trabalho intensivo, regular e compulsório (FAUSTO, 2006, p. 22). Outro fator relevante foi a catástrofe demográfica sofrida pela população indígena. Eles foram acometidos por doenças como sarampo, varíola e gripe, trazidas pelo homem branco, que dizimaram cerca de $60 \mathrm{mil}$ nativos. (FAUSTO, 2006, p. 23).

Contudo, o aspecto principal para a preferência da mão de obra africana foi o interesse da Coroa e dos traficantes de escravos. 
A captura dos indígenas transformou-se em um negócio interno da colônia, gerando, desta forma, prejuízos à metrópole, uma vez que essa deixava de arrecadar o Quinto, (imposto cobrado sobre a propriedade) sonegado pelos portugueses que aqui se estabeleceram. Por outro lado, o comércio transatlântico de escravos trazia excelentes dividendos, tanto ao governo, quanto aos comerciantes. Assim, ao impor limitações ao trabalho escravo indígena, a metrópole e os jesuítas acabavam por apoiar de maneira indireta os traficantes de escravos, que encontraram no Brasil uma excelente oportunidade de negócios (PINSKY, 2010, p. 22).

A Coroa, então, passou a tomar medidas legais que impedissem o morticínio e a escravização desenfreada da população indígena. Porém, tais medidas continham ressalvas, e eram facilmente burladas, permitindo a escravização em decorrência de "guerras justas”, ou como castigo pela antropofagia. (FAUSTO, 2006, p. 23).

Os índios resistiram às várias formas de sujeição, pela guerra, pela fuga, pela recusa ao trabalho compulsório. Em termos comparativos, as populações indígenas tinham melhores condições de resistir do que os escravos africanos. Enquanto estes se viam diante de um território desconhecido onde eram implantados à força, os índios se encontravam em sua casa. (FAUST0,2006, p. 23)

Diante de todas estas circunstâncias, a mão de obra escrava africana mostrava-se extremamente vantajosa, vez que gerava gordos impostos a Coroa. Desta forma, foi principalmente por motivos egoísticos e gananciosos que a escravidão do índio foi aos poucos suprimida pela escravidão do negro, que a partir daí se tornou protagonista do trabalho escravo em nosso país por mais de 300 anos. 


\subsection{A ESCRAVIDÃO NEGRA}

As primeiras levas de escravos foram trazidas em 1538, estabelecendo-se assim uma duradoura ligação com o continente africano, fortalecida principalmente pelo tráfico, que perdurou até 1850, ano que marcou o início de seu declínio (VICENTINI; RIBEIRO; PEREIRA, 2014, p.188). Como visto anteriormente, para sustentar o sistema colonial era necessária alta produção a baixo custo, impossibilitando a implementação do trabalho livre na colônia. Diante destas condições, para suprir as demandas exigidas pela sociedade europeia, sem encarecer os custos de produção, trouxeram os negros ao Brasil. Inicialmente foram inseridos nas lavouras com a finalidade de servir como mão de obra em trabalhos pesados, bem como no transporte de cargas (MESGRAVIS, 2015, p. 42).

Porém, não só a necessidade de mão de obra foi aspecto fundamental para a introdução da escravidão negra no Brasil. "A maneira de ocupar e explorar terras e vidas humanas só ganha significado quando pensada em relação às necessidades do capitalismo comercial em desenvolvimento na Europa" (VITA, 2004, p. 13). Ou seja, quanto maior o consumo europeu, maior era a exigência de produção. Consequentemente, aumentava também a necessidade de mão obra escrava nas lavouras brasileiras, intensificando e fortalecendo o comércio ilegal de africanos para o Brasil. 0 estabelecimento da escravidão negra na colônia assegurava aos traficantes e a própria burguesia europeia excelentes rendimentos. Assim, a compra e venda destes seres humanos estimulou por séculos a economia da metrópole:

O ponto decisivo para compreender a escravidão negra é o próprio tráfico de escravos. Este foi um negócio altamente lucrativo controlado pela burguesia metropolitana. Para ela, a introdução e permanência da escravidão significavam a certeza de continuar embolsando gordos lucros auferidos 
através da captura de negros na África e sua venda aos senhores de terra brasileiros. (VITA; 2004, p. 14).

O grande negócio dos europeus passou a ser a captura e travessia de negros do continente africano. Este comércio movimentou imenso capital, em termos comparativos, absorveu, no futuro, pelo menos metade do valor do açúcar e, depois, do ouro (RIBEIRO, 1995, p. 161). Ou seja, "Antes mesmo de começar a arrancar riquezas da terra com seu trabalho, como propriedade do senhor, o escravo já produzia lucro" (VITA, 2004, p. 14).

Os negros eram considerados mercadoria, poderiam ser alugados, trocados ou vendidos em caso de necessidade. Assim, os escravos possuíam duplo valor, pois ao mesmo tempo que produziam por meio de seus serviços, valiam também como moeda de troca. (COSTA, 1998, p.14). Apesar da existência da escravidão no continente africano ser anterior a chegada dos europeus, ela tomou proporções globais em âmbito comercial e econômico após a chegada destes:

Embora a escravidão já existisse na África Ocidental antes da chegada dos europeus, ela assumiu outro significado. Doravante, o cativo tornou-se uma "peça", termo que evoca por si mesmo sua condição de mercadoria, cujo valor podia oscilar de acordo com a lei de oferta e procura. Essa escravidão em massa, por sua vez, inundou a Europa, e depois toda a América, com uma categoria social completamente privada de direitos que passava a constituir a base de toda a exploração econômica, motivo pelo qual certos pesquisadores identificam a existência de organizações sociais escravistas específicas na era moderna. (MACEDO, 2013, p. 105)

A obtenção de escravos se dava das mais variadas formas, eles eram capturados, enganados ou atraídos pelo tabaco, aguar- 
dente ou tecidos. Os Europeus estimulavam guerras tribais e forneciam armas para tribos rivais, com vistas a obtenção de novos escravos (MESGRAVIS, 2015, p. 38). Com o tempo os métodos utilizados para a captura e transporte dos cativos foram aprimorados. Por meio de operações militares os europeus invadiam as aldeias e, com armas de fogo, matavam idosos e capturavam homens, mulheres e crianças. Cerceados de liberdade, os escravos eram acorrentados por meio de um limbambo, que consistia em um instrumento de ferro que unia os cativos pelo pescoço. (MATTOS, 2007, p. 77)

Eles eram então transportados ao Brasil em navios negreiros, lugar onde "A fome, a sujeira, o desconforto e a morte eram companheiros de viagem dos negros" (PINSKY,2010, p. 37). Foram nestas condições que "No porão dos navios negreiros, por mais de 300 anos, cruzaram o Atlântico cerca de três milhões de africanos. Um a cada cinco escravos não sobrevivia à viagem para o Brasil" (PINTO JÚNIOR; CARDOSO, 2015, p.27).

Ocorria, portanto, um duplo desenraizamento. Primeiro eles foram retirados à força da comunidade e do local em que viviam. Depois, transportados para terras distantes, onde eram submetidos a regras e formas culturais estranhas aos seus costumes. Por último, eram reinseridos em outro grupo em posição de subordinação, tinham seus corpos violados, e eram excluídos e desprovidos de convivência na nova comunidade (MACEDO, 2013, p. 103).

Os escravos eram considerados reles propriedade de seus senhores, desta forma, a violência e a injustiça eram cotidianas. Eles trabalhavam incessantemente, de sol a sol, sofriam castigos de maneira arbitrária e viviam em condições subumanas. Os negros, assim como os índios, também tentaram resistir por meio de fugas, assassinatos de senhores, e criação de quilombos. Todavia, a Igreja e a Coroa portuguesa não se opuseram a escravidão, ao contrário disso, justificaram-na. (MARTINS; MACHADO, 2004, p. 17). 


\subsection{O DECLÍNIO DA ESCRAVIDÃO}

Em meio ao sistema escravocrata que vigorava no Brasil, levantava-se na Inglaterra e na França, no século XVIII, o Iluminismo, movimento filosófico e cultural, influenciado por pensadores que propagavam ideais de igualdade, liberdade, dignidade humana, e liberalismo econômico. Tal movimento traria a ruína do absolutismo monárquico. (LOBO; PORTELA, 2017, p.179). Nesse contexto:

A implantação definitiva da sociedade capitalista na Europa Ocidental resultou da Revolução Francesa de 1789 e da Revolução Industrial, que se iniciou na Inglaterra nos últimos 25 anos do século XVIII (VITA, 2004, p. 16).

Tais revoluções culminaram no início da decadência do trabalho escravo em âmbito global. No Brasil, entretanto, o cenário da escravidão não sofreu alterações significativas, perdurando praticamente imutável por mais de três séculos. 0 processo de independência e de formação do Estado nacional brasileiro (entre 1808 e 1822) não importou em grandes mudanças sociais. Nessa época 19/20 da população brasileira era composta por escravos e homens livres pobres, ou seja, mestiços, sem acesso à propriedade de terras, uma vez que esse privilégio era negado aos "não brancos". Assim, sendo o mercado brasileiro voltado a exploração da mão de obra escrava, restava aos mulatos e caboclos livres apenas tarefas secundárias e pouco valorizadas. (VITA, 2004, p.15). Portanto, podemos afirmar que:

A independência política do Brasil (1822) estabeleceu a autonomia em relação a Portugal, entretanto a jovem nação iniciava sua trajetória de país independente com um elevado número de escravos e sob o estigma do poder dos latifundiários. (MARTINS; MACHADO, 2004, p. 23). 
Em 1807 a Inglaterra aboliu o comércio de escravos em suas colônias. Um ano depois, em 1808, D. João VI encontrava-se em dívida com os ingleses, que o auxiliaram por meio da marinha britânica na sua evasão de Portugal para o Brasil. Aproveitando-se das obrigações em que ficara o monarca português, a Inglaterra tentou suprimir o tráfico de escravos para o Brasil. D. João VI por sua vez, fazia apenas promessas vagas em relação ao assunto. (COSTA, 1998, p.74).

Logo, o colapso da escravidão no Brasil ocorreu, primeiramente, devido as pressões externas promovidas pela Inglaterra, que passava por um rápido desenvolvimento industrial. Interessava aos ingleses neocolonialistas apenas os países que, além de fornecerem matéria-prima e alimentos em grande quantidade, servissem também como mercado consumidor de seus produtos industrializados. Nesse sentido, a escravidão mostrava-se como um verdadeiro obstáculo para a satisfação e efetivação do capitalismo industrial inglês. Somente com a generalização do trabalho livre haveria a possibilidade de ampliação do mercado consumidor. A sociedade brasileira, portanto, não atendia as exigências inglesas, vez que a maioria de sua população era escrava. Desta forma, na primeira metade do século XIX, a Inglaterra passou a exercer forte influência no processo abolicionista, combatendo com extremo rigor o tráfico de escravos e a escravidão (VITA, 2004, p. 16).

Após a independência, o governo brasileiro encontrava-se em uma situação complicada. Afora vozes isoladas, não apenas grandes proprietários e traficantes, como toda a população livre estavam convencidos de que o fim do tráfico de escravos, a curto prazo, provocaria um colapso na sociedade. (FAUSTO, 2006, p. 104)

Em 1822 a Inglaterra, compreendendo as dificuldades brasileiras, propôs como condição preliminar para o reconhecimento 
da independência do país, a assinatura de acordo abolindo o tráfico de africanos (DUQUE ESTRADA, 2005, p.29). Essa pretensão foi consubstanciada em um tratado que fora assinado em 1826, formalizando o reconhecimento da independência do Brasil. 0 referido tratado entrou em vigor em 1827, daí em diante o Brasil comprometeu-se em coibir o tráfico de escravos no prazo de 3 anos, ou seja, até 1830 (COSTA, 1998, p.75).

Em 1831, buscando dar andamento ao que fora estabelecido entre Brasil e Inglaterra, foi publicada a lei que previa duras sanções aos traficantes, e declarava como livres todos os cativos que entrassem no Brasil. Entretanto, a lei de 1831 foi considerada "lei para inglês ver" uma vez que não surtiu o efeito esperado, e logo o fluxo de transporte e comércio de escravos voltou a crescer (FAUSTO, 2006, p. 107). Desta forma, verifica-se que apesar dos esforços empregados pelos ingleses, o tráfico de escravos era de difícil combate tendo em vista que se mostrava como um negócio muito lucrativo e de interesse da Coroa portuguesa:

O governo português concordava em decretar a suspensão do tráfico no mais breve prazo possível. $\mathrm{Na}$ realidade, nada fez de concreto para cumprir o compromisso assumido e o tráfico continuou a ser feito livremente (COSTA, 1998, p.75).

Já em 1845, por meio da Lei Bill Aberdeen, a Inglaterra passou a fiscalizar os navios suspeitos de tráfico negreiro, entretanto, a medida não afetou os números de escravos que desembarcavam no Brasil. 0 tráfico continuava intenso, mesmo de maneira ilegal (FELIPE, 2015, p. 325).

\subsection{A INEFICÁCIA DAS LEIS ABOLICIONISTAS}

As leis abolicionistas que antecederam a extinção da escravidão ficaram conhecidas popularmente pelo termo "leis para inglês ver", uma vez que tinham sua eficácia comprometida diante 
das circunstâncias exigidas para a obtenção da liberdade pelos negros. Tratavam-se, desta forma, de leis criadas apenas para satisfazer superficialmente as pressões exercidas pela Inglaterra, porém, elas não garantiam aos escravos a liberdade de maneira plena. Daí em diante esta expressão passou a ser utilizada para referenciar algo que diz respeito apenas a aparências, mas que não se cumpre efetivamente (FAUSTO, 2006, p. 105).

\subsubsection{Lei Eusébio de Queirós}

0 cerco à escravidão estava se fechando, e o processo abolicionista começava a se desenhar, "O governo de D. Pedro II e os latifundiários brasileiros não conseguiram resistir a essa pressão inglesa por muito tempo" (VITA, 2004, p. 17). Em 04 de setembro de 1850 foi promulgada a Lei Imperial no 581, considerada um dos marcos abolicionistas mais relevantes de nossa história. A lei Eusébio de Queirós proibia definitivamente o tráfico de escravos no Brasil. Assim dispunha o Art. 1ำ da referida lei:

Art. $1^{\circ}$ As embarcações brasileiras encontradas em qualquer parte, e as estrangeiras encontradas nos portos, enseadas, ancoradouros, ou mares territoriaes do Brasil, tendo a seu bordo escravos, cuja importação he prohibida pela Lei de sete de Novembro de mil oitocentos trinta e hum, ou havendo-os desembarcado, serão apprehendidas pelas Autoridades, ou pelos Navios de guerra brasileiros, e consideradas importadoras de escravos.

Aquellas que não tiverem escravos a bordo, nem os houverem proximamente desembarcado, porêm que se encontrarem com os signaes de se empregarem no trafico de escravos, serão igualmente apprehendidas, e consideradas em tentativa de importação de escravos (BRASIL, 1950, paginação irregular).

O tráfico de escravos passou a ser considerado pirataria, logo, ficava submetido a duras sanções. As embarcações apre- 
endidas deveriam ser vendidas com toda a carga encontrada a bordo. Posterior, o produto da venda era dedicado aos seus apresadores, responsáveis pela captura do navio. Deduzia-se deste valor um quarto para o denunciante. Ficou estipulado que os escravos apreendidos deveriam ser reexportados, por conta do Estado, para seus locais de origem, ou algum outro que fosse conveniente (COSTA, 1998, p.83).

No entanto, a lei deixava algumas brechas, uma vez que determinava que enquanto não fosse efetuada a reexportação dos cativos, estes seriam empregados em trabalhos sob tutela do governo. Desta forma, quando tal exigência não era levada adiante, os cativos eram entregues aos senhores, e para eles deveriam trabalhar pelo prazo de quatorze anos, após esse período seriam considerados emancipados. (COSTA, 1998, p.83).

Mesmo diante de inúmeros percalços, após efetiva fiscalização, dessa vez a lei "pegou". "A entrada de escravos no país caiu de cerca de 54 mil cativos em 1849 para menos de 23 mil em 1850 e em torno de 3300 em 1851, desaparecendo praticamente a partir daí. " (FAUSTO, 2006, p. 106).

\subsubsection{Lei do Ventre Livre}

Em 28 de setembro de 1871 foi aprovada a Lei Imperial $\mathrm{n}^{\circ}$ 2040, também chamada Lei do Ventre Livre. A referida normativa estabelecia que seriam declarados livres os filhos de escravas nascidos após a sua promulgação. Na realidade podemos afirmar que tal lei era de fato falaciosa, uma vez que não concedia de pronto a liberdade aos rebentos das escravas. Aqui vale lembrar que os recém-nascidos, obviamente, eram dependentes dos cuidados maternos e amamentação de suas genitoras, que, todavia, continuavam escravizadas. Após a promulgação da lei, muitas crianças foram tomadas de suas mães, que eram obrigadas a abortar, ou abandonar a sua prole. Aos olhos dos senhores de escravos um recém-nascido liberto não passava de despesa (FONSECA, 2009, p. 61). 
Mais falaciosa ainda era a suposta liberdade declarada pela lei, que exigia a anuência do senhor de escravos para que a criança ficasse com a mãe. Nesta hipótese o escravista poderia optar entre a utilização dos serviços do menor até que esse completasse 21 anos, ou dar-lhe a liberdade aos 8 anos, mediante indenização de $600 \$ 000$ réis paga pelo Estado. (DUQUE ESTRADA, 2005, p. 57). Assim dispunha o Art. $1^{\circ}, \S 1^{\text {o }}$ da referida lei:

Art. $1^{\circ}$ Os filhos de mulher escrava que nascerem no Imperio desde a data desta lei, serão considerados de condição livre.

$\S 1^{\text {o }}$ Os ditos filhos menores ficarão em poder o sob a autoridade dos senhores de suas mãis, os quaes terão obrigação de crial-os e tratal-os até a idade de oito annos completos. Chegando o filho da escrava a esta idade, o senhor da mãi terá opção, ou de receber do Estado a indemnização de 600\$000, ou de utilisar-se dos serviços do menor até a idade de 21 annos completos. No primeiro caso, o Governo receberá o menor, e lhe dará destino, em conformidade da presente lei. A indemnização pecuniaria acima fixada será paga em titulos de renda com o juro annual de 6\%, os quaes se considerarão extinctos no fim de 30 annos. A declaração do senhor deverá ser feita dentro de 30 dias, a contar daquelle em que o menor chegar á idade de oito annos e, se a não fizer então, ficará entendido que opta pelo arbitrio de utilizar-se dos serviços do mesmo menor. (BRASIL, 1871, paginação irregular)

Ou seja, "Tal proposta era, como se vê, uma ridícula mistificação, criando para os nascituros uma situação em tudo comparável à do cativeiro, até que atingissem a maior idade" (DUQUE ESTRADA, 2005, p. 57). 


\subsubsection{Lei do Sexagenário}

Em 28 de setembro de 1885, foi promulgada a Lei Imperial no 3.270, também conhecida por Lei Saraiva Cotegipe ou Lei dos Sexagenários. De acordo com o Artigo 3ํㅜ $§ 10$ da lei, os cativos que atingissem 60 anos seriam considerados libertos, porém deveriam atender a uma condição: eram obrigados a prestar serviços a seus senhores pelo período de três anos, a título de indenização pela alforria concedida (BRASIL, 1885) A norma legal estipulava ainda a garantia de liberdade aos escravos com mais de 65 anos, entretanto, poucos negros expostos às condições subumanas da escravidão conseguiam atingir essa idade. Mesmo assim, a lei enfrentou forte resistência dos senhores de escravos. (FONSECA, 2009, p. 60).

Art. $3^{\circ}$ Os escravos inscriptos na matricula serão libertados mediante indemnização de seu valor pelo fundo de emancipação ou por qualquer outra fórma legal.

[...]

$\S 10$. São libertos os escravos de 60 annos de idade, completos antes e depois da data em que entrar em execução esta Lei; ficando, porém, obrigados, a titulo de indemnização pela sua alforria, a prestar serviços a seus ex-senhores pelo espaço de tres annos.

$\S 11$. Os que forem maiores de 60 e menores de 65 annos, logo que completarem esta idade, não serão sujeitos aos alludidos serviços, qualquer que seja o tempo que os tenham prestado com relação ao prazo acima declarado. (BRASIL, 1885, paginação irregular)

Em verdade, a lei dos Sexagenários tornou os escravos idosos ainda mais vulneráveis e suscetíveis ao abandono. Após prestarem serviços por toda uma vida, quando já não podiam mais produzir renda ao escravista, eram "libertos". 0 resultado disso 
foi que milhares de idosos foram abandonados à sorte do destino. A suposta liberdade não os livrou dos grilhões da condição miserável em que viviam, tampouco garantiu-lhes a dignidade efetiva. Muitos foram viver nas ruas, porém a maioria permaneceu servindo a seus algozes, fruindo de uma pseudoliberdade e submetendo-se às tiranias e vilanias de feitores e capatazes. Desta forma é possível afirmar que a referida normativa não gerou qualquer melhoria na condição de vida dos escravos, pelo contrário, favoreceu o desamparo de milhares de idosos sob a falsa justificativa de concessão da liberdade (FONSECA, 2009, p. 60). A Lei dos Sexagenários foi um dos marcos indicadores à sociedade brasileira de que a escravidão perecia e que o Brasil rumava a caminho da abolição. (FONSECA, 2009, p. 60).

\subsection{A LEI ÁUREA E O CONTEXTO PÓS ABOLIÇÃO}

Em 13 de maio de 1888, foi assinada pela Princesa Isabel a Lei Imperial no 3.353, comumente chamada de Lei Áurea, que extinguiu, finalmente, a escravidão. Assim dispunham os artigos $1^{\circ}$ e $2^{\circ}$ da referida lei:

A Princesa Imperial Regente, em nome de Sua Majestade o Imperador, o Senhor D. Pedro II, faz saber a todos os súditos do Império que a Assembléia Geral decretou e ela sancionou a lei seguinte: Art. $1^{\circ}$ : É declarada extincta desde a data desta lei a escravidão no Brazil.

Art. $2^{\circ}$ : Revogam-se as disposições em contrário (BRASIL, 1888, paginação irregular).

A abolição da escravidão se tornou inevitável. Manter o sistema escravista passou a ser economicamente inviável, e politicamente insustentável tanto em âmbito nacional quanto em âmbito de política internacional. (FONSECA, 2009, p. 63).

Entretanto, a Lei Áurea não refletiu verdadeiramente a libertação dos negros escravizados. Em 1888 foi decretada a imediata 
extinção da escravidão, sem qualquer indenização aos senhores de escravos, porém, a norma não previa qualquer medida com o condão de integrar o negro a sociedade. Aos libertos não foi ofertado sequer um pedaço de terra onde pudessem plantar, tampouco tiveram acesso à educação (DOLHNIKOFF, 2017, p.128).

Ademais, muitos negros já se encontravam libertos por conta e risco. 0 dispositivo legal atingiu apenas 5,6\% de escravizados, cerca de 1 milhão de negros de uma população estimada em 15 milhões. Este número ínfimo justifica-se pelas leis anteriores, pelos levantes dos negros contra a escravidão, pela varíola e demais epidemias, pela Guerra do Paraguai, e outras revoltas tais como a Cabanagem, a Balaiada, a Revolta do Malês, e Revolução Farroupilha. (FONSECA, 2009, p. 63). Como consequência, os ex-escravos deixaram as fazendas, e passaram a se estabelecer em terrenos baldios, onde acampavam livres, vivendo como em quilombos, alimentando-se basicamente de milho e mandioca. Acabaram, desta forma, caindo em situação de extrema miserabilidade, e sua população reduziu-se substancialmente. (RIBEIRO, 1995, p.221).

A nação brasileira, construída nos ombros de homens e mulheres escravizados, nunca fez nada para amenizar a condição do negro no pós abolição. Essa população ficou completamente desprovida de assistência por parte Estado, que lhes negou terras onde pudessem viver e cultivar, e escolas onde pudessem educar seus filhos. Restou-lhes apenas discriminação e repressão. Muitos libertos dirigiram-se às cidades, onde encontraram um ambiente menos hostil, e construíram bairros africanos, dando lugar as atuais favelas, que até hoje se multiplicam como solução de moradia para pessoas de baixa renda. (RIBEIRO, 1995, p.222).

A passagem do trabalho escravo para o trabalho livre também marcou a formação da sociedade brasileira. Após extinta a escravidão, negros e seus descendentes esbarraram em dificuldades para ingressar no mercado de trabalho livre. Neste período de nossa história, o governo republicano representava os interesses 
dos cafeicultores. Surgiu, então, a promoção de campanhas em favor do branqueamento e europeização da população brasileira, visando a erradicação da herança biológica e cultural africana (MATTOS, 2007, p.186).

Além de estimular a imigração para o Brasil, o governo republicano destinou também recursos próprios para a vinda dos europeus, o que propiciou a exclusão dos negros no mercado de trabalho formal. Como resultado destas ações estatais imigrantes de toda a Europa vieram ao Brasil em grandes quantidades. Alemães, italianos, espanhóis e portugueses assumiram a mão de obra em áreas rurais e urbanas, principalmente como colonos. Restaram aos negros as ocupações mais penosas, menos qualificadas e normalmente informais (MATTOS, 2007, p.186).

A solução encontrada pelos grandes proprietários de áreas rurais foi, portanto, a utilização da mão de obra dos imigrantes europeus, que concordavam em trabalhar para o fazendeiro na esperança de um dia tornarem-se proprietários da terra. Tínhamos, então, enraizada entre os colonos uma ideologia de valorização do trabalho. Estes acreditavam que o esforço e labuta contínua eram a chave para conseguir a própria independência. Entretanto, esta ideologia foi deturpada frente ao regime escravocrata, que maculou a própria ideia de trabalho (VITA, 2004, p. 41).

A desvalorização do labor neste regime cruel impediu que a mão de obra negra fosse utilizada para o trabalho livre. Para o escravo, trabalho e escravidão tornaram-se uma só coisa, assumindo o mesmo significado. Assim, para aqueles que vivenciaram os horrores da escravidão, liberdade significava não ter que trabalhar para terceiros. Por consequência, fazendeiros e intelectuais da época entenderam essa deformação da ideia de trabalho, como uma deformação moral dos negros, que eram vistos como vadios, preguiçosos, e incapazes de integrar-se à sociedade. Os ex-escravos livraram-se do cativeiro, porém não conseguiram desvincular de sua imagem o preconceito racial e inferiorização social (VITA, 2004, p. 41). 


\section{DESIGUALDADES SOCIAIS E O TRATAMENTO CONSTITUCIONAL}

Apontado o contexto histórico que marcou a presença do negro em nossa sociedade, podemos afirmar que a escravidão consistiu em fator fundamental para a existência de desigualdades sociais em nosso país.

O fim da escravatura, da qual o Brasil foi o último a se livrar, não aboliu o monopólio da terra, fonte de poder econômico e principal meio de produção até as primeiras décadas do século XX. A classe dos trabalhadores brasileiros fez-se com a importação de mão de obra imigrante e com a exclusão dos trabalhadores nacionais. (SANTOS, 2009, p.16)

Diante da urbanização e do crescimento populacional, a disparidade de concentração de renda tornou-se mais evidente. Consequentemente, as desigualdades sociais aprofundaram-se jogando a margem da sociedade a maior parte dos brasileiros, sobretudo a população negra. Brancos letrados, donos de terra, com direito a voto e a expressão ganharam o topo da pirâmide social. $\mathrm{Na}$ base, permaneceram os cidadãos não brancos, e sem acesso a escolaridade (SANTOS, 2009, p.16). A mentalidade escravocrata reflete suas consequências até os dias atuais, na medida em que vemos que os negros no Brasil necessitam de legislação especial para combater a discriminação racial, que perdura desde os primórdios de nossa história (MARTINS; MACHADO, 2004, p. 18).

A desigualdade social no Brasil já iniciou no período colonial, mais especificamente no Nordeste brasileiro, onde havia os grandes engenhos de açúcar. Os proprietários destes engenhos eram muito ricos[...]. Na escala social, abaixo desta classe mais alta existia um número razoável de trabalhadores livres que viviam muito modestamente. Por fim, vivendo nas piores condições possíveis estavam 
os escravos. Entretanto, podemos afirmar que estas diferenças sociais não surgiram por acaso, ou porque uns gostavam de trabalhar mais e outros menos, mas por causa de uma exploração que existiu desde os inícios da nossa colonização e que não deu igualdade de condições a todos que aqui viviam. (MARTINS; MACHADO, 2004, p.19)

Cem anos após declarada extinta a escravidão, apenas em 1988, foi promulgada a atual Constituição Federal, conhecida também como constituição cidadã, concebida após um longo processo de redemocratização, marcando o fim da ditadura militar:

A Constituição brasileira de 1988 tem, antes e acima de tudo, um valor simbólico: foi ela o ponto culminante do processo de restauração do Estado democrático de direito e da superação de uma perspectiva autoritária, onisciente e não pluralista de exercício do poder, timbrada na intolerância e na violência. (BARROSO, 2002, p.10)

Pela carta magna foram concebidos direitos e garantias fundamentais, bem como normas programáticas, metas, e objetivos a serem alcançados pelo Estado. Aqui, vale salientar o disposto no Art. 3o da nova Carta Política, que elenca como objetivos fundamentais da República Federativa do Brasil:

I - construir uma sociedade livre, justa e solidária;

II - garantir o desenvolvimento nacional;

III - erradicar a pobreza e a marginalização e reduzir as desigualdades sociais e regionais;

IV - promover o bem de todos, sem preconceitos de origem, raça, sexo, cor, idade e quaisquer outras formas de discriminação. (BRASIL,1988, paginação irregular). 
Tratam-se, portanto, de Princípios Programáticos, ou seja, ainda que não tenham sido devidamente efetivados, ou tenham sido adotados de maneira insuficiente, consistem em objetivos permanentes a serem concretizados pelo governo. (MARTINS, 2005, p.24). Ou seja, sua realização tem caráter de busca contínua, ainda que tenham sido superficialmente alcançados, tais objetivos estão sempre sujeitos ao aperfeiçoamento pelo Estado. (HACK, 2012, p. 65)

[...] a Carta brasileira de 1988 é dirigente. 0 termo, trazido do constitucionalismo português, identifica uma opção pela inclusão no texto constitucional de grandes linhas programáticas, que procuram sinalizar caminhos a serem percorridos pelo legislador e pela Administração Pública. Estabelecem-se fins, tarefas e objetivos para o Estado e para a sociedade. (BARROSO, 2002, p. 14)

Em uma linha de raciocínio lógico, a erradicação da pobreza se comunica com o objetivo de garantir o desenvolvimento econômico nacional. Consequentemente, as pessoas que vivem em situação de pobreza seriam, desta forma, reinseridas na sociedade, eliminando por sua vez o fenômeno da marginalização. Tais metas devem ser paralelas a redução das desigualdades sociais e regionais que visam, sobretudo, a diminuição das diferenças existentes entre os mais ricos e os mais pobres, bem como o estímulo ao avanço igualitário das diversas regiões brasileiras. Entretanto, a superação das mazelas sociais exige que sejam observados demais aspectos essenciais a uma vida digna, tais como: educação, saúde, segurança, moradia, alimentação, etc. (HACK, 2012, p.66).

É correto afirmar, portanto, que as normas programáticas traçam fins sociais a serem atingidos pela atuação futura do poder público. Devido a sua natureza, não dão ao jurisdicionado a opção de exigir comportamentos comissivos, não obstante, investe 
a faculdade de exigir dos órgãos estatais que se abstenham de qualquer atuação que se contraponha às diretrizes previamente estabelecidas na constituição. Em vista disso, a redução das desigualdades sociais ingressa na categoria de norma constitucional programática. (BARROSO, 2002, p. 81).

Assim, podemos concluir que o desequilíbrio social existente entre brancos e negros, atualmente tão evidente em nossa sociedade, decorre de um longo processo de escravização e exploração de vidas humanas, que colocou o afro-brasileiro na base da pirâmide social. O legislador constituinte, por sua vez, preocupou-se em atribuir tratamento constitucional ao tema, dada a sua importância ao desenvolvimento da nação. Garantiu, portanto, o empenho do Estado em reduzir as desigualdades sociais que o próprio promoveu por séculos.

\section{A UTILIZAÇÃO DE AÇÕES AFIRMATIVAS NO COMBA- TE ÀS DESIGUALDADES SOCIAIS}

A Constituição Federal de 1988 positivou a luta contra as desigualdades. Neste contexto, e na esteira de movimentos sociais, surgiram as políticas de ações afirmativas, dentre elas o sistema de cotas raciais.

É importante esclarecer que as ações afirmativas não se confundem exclusivamente com a política de cotas. Podemos classificar como ações afirmativas as medidas estatais e as medidas privadas voltadas para a integração socioeconômica dos grupos discriminados, mantendo sua identidade sociocultural. Por isso, [...] ressalta-se que as ações afirmativas não são atos de caridade nem de clientelismo. Estão pautadas pelo reconhecimento da identidade e o pertencimento cultural dos grupos sociais, o que significa partir das demandas que apresentam reconhecendo-as como direito. (MIRANDA, 2010, p.30) 
Assim, as ações afirmativas em sua essência consistem basicamente em: "políticas públicas destinadas a atender grupos sociais que encontram-se em posição de desvantagem ou vulnerabilidade social em decorrência de fatores históricos, culturais, e econômicos. " (FONSECA, 2009 p.11).

A crítica esboçada em relação ao tema decorre da obrigação estatal de promover o bem de todos, sem preconceitos. Assim, ainda que estas ações se destinem a retirar as minorias da condição de exclusão social, o Estado acaba por promover uma política discriminatória (MARTINS, 2005, p. 26). Desta forma, com relação às cotas em universidades, o poder público deve primeiramente fornecer um ensino básico de qualidade e igualdade de condições, para que todos possam concorrer, para só então fornecer auxílio financeiro a quem dele necessite Nesta perspectiva, a Administração precipita-se ao lançar ações afirmativas em Universidades sem antes fundar alicerces fundamentais e promover igualdade de condições desde o ensino básico. Ademais, a constituição federal de 1988 veda qualquer tipo de discriminação, portanto, a fundamentalidade do princípio da igualdade não pode representar qualquer distinção contrária as maiorias que, neste caso, perderiam espaço para as minorias qualificadas (MARTINS, 2005, p. 27).

Em contraponto a este posicionamento, as ações afirmativas justificam-se pois foram criadas para reparar situações originadas a partir de um processo histórico de exclusões, que se relacionam intimamente com a discriminação racial vivida pelos negros no Brasil. Estas políticas tratam-se, portanto, de dispositivos estratégicos que promovem a inclusão social, com fundamento no princípio da discriminação positiva. Não se comparam a medidas assistencialistas de caráter emergencial ou pontual, pois estas são caracterizadas pela provisoriedade e benevolência. As referidas medidas são, na verdade, políticas estrategicamente planejadas e articuladas, que visam a redução das desigualdades sociais (AMARO, 2015). 
Portanto, tais políticas públicas de inclusão estão em consonância com as normas programáticas aludidas em nosso ordenamento jurídico pátrio. As referidas ações consistem em atos de discriminação lícita, potencialmente capazes de mitigar os prejuízos históricos advindos da escravidão, causadores de profundas desigualdades sociais entre brancos, negros e pardos em nosso país. Assim, "As ações afirmativas, quando consolidadas nos preceitos constitucionais, são a promoção da justiça social e da dignidade da pessoa humana" (MELLO; MOREIRA, 2015, p. 281).

\subsection{A RELATIVIZAÇÃO DO PRINCÍPIO DA IGUALDADE}

Diante desta espécie de "justiça compensatória", surgiram inúmeras oposições às ações afirmativas. Dentre os mais diversos argumentos levantados pelas massas, estão aqueles relativos a violação ao princípio da igualdade, um dos pilares de nosso ordenamento jurídico pátrio. Sua previsão é referenciada no caput do artigo 5ํ da Constituição Federal de 1988, com a seguinte redação:

Todos são iguais perante a lei, sem distinção de qualquer natureza, garantindo-se aos brasileiros e aos estrangeiros residentes no País a inviolabilidade do direito à vida, à liberdade, à igualdade, à segurança e à propriedade, nos termos seguintes. (BRASIL, 1988, paginação irregular)

Podemos afirmar, portanto, que o referido princípio se consolidou como um dos fundamentos básicos de todo o arcabouço legal brasileiro. Vale destacar a relevância dada pelo legislador constitucional ao Princípio da Igualdade, uma vez que esse é aludido por duas vezes consecutivas no caput do artigo $5^{\circ}$, da atual Carta Magna. A normativa inaugura o Título II da Constituição Federal de 1988, estrutura relativa aos direitos e garantias fundamentais de nosso ordenamento jurídico: 
O que mais impressiona, todavia, é que no texto desse artigo, há menção ao mesmo direito duas vezes: "todos são iguais perante a lei", e depois se garante a inviolabilidade do "direito à igualdade". Isso equivale a dizer que nosso constituinte considerou fundamental a igualdade de todos os brasileiros e dos estrangeiros aqui residentes, no sentido de não poder haver nenhuma espécie de discriminação. (MARTINS; 2005, p. 37)

Importante salientar que tal princípio guarda íntima relação com o Direito Administrativo, ramo do direito público voltado a dar fiel execução a lei, regulando, toda a atuação estatal. Nesse sentido, é conferida verdadeira importância a Impessoalidade no universo da Administração pública brasileira:

É o princípio - também denominado da isonomia ou da generalidade - que domina todo o universo jurídico, mas é no Direito Administrativo que ganha especial e frequente aplicação, ao proscrever qualquer tratamento diferenciado entre os administrados, que não se fundamente em lei prévia que, por sua vez, haja garantido generalidade de tratamento a todos os que se encontram na idêntica situação de fato tomada como base de igualação, desprezados os elementos acidentais diferenciadores. (MOREIRA NETO; 2014, p. 87)

Feitos tais apontamentos, merece destaque o disposto no artigo. 37, incisos, I, e II, da Constituição Federal de 1988, que assim aduz:

Art. 37. A administração pública direta e indireta de qualquer dos Poderes da União, dos Estados, do Distrito Federal e dos Municípios obedecerá aos princípios de legalidade, impessoalidade, moralidade, publicidade e eficiência e, também, ao seguinte: 
I - os cargos, empregos e funções públicas são acessíveis aos brasileiros que preencham os requisitos estabelecidos em lei, assim como aos estrangeiros, na forma da lei;

II - a investidura em cargo ou emprego público depende de aprovação prévia em concurso público de provas ou de provas e títulos, de acordo com a natureza e a complexidade do cargo ou emprego, na forma prevista em lei, ressalvadas as nomeações para cargo em comissão declarado em lei de livre nomeação e exoneração; (BRASIL, 1988, paginação irregular)

Tal normativa constitucional declara a Impessoalidade como princípio norteador da Administração Pública. Logo, fica expressamente determinado que o Poder Público deverá obedecer ao Princípio da Impessoalidade para a investidura em cargos e empregos públicos. Ocorre que, em oposição a esta normativa, foi sancionada em junho de 2014 a Lei 12.990, também denominada Lei de Cotas. A referida legislação tem por escopo reduzir os contrastes étnico-raciais existentes no âmbito do serviço público federal:

A reserva de vagas se aplica sempre que o número de vagas oferecidas no concurso público é igual ou superior a três. [...] A Lei de Cotas surgiu para reduzir a discrepância de negros e pardos entre o serviço público federal e a população geral do país. Hoje $53 \%$ da população brasileira se declara negra. Nas repartições federais, o índice cai para menos de 35\%. (SENADO, 2017, paginação irregular)

A referida lei estabelece em seu artigo $1^{\circ}$, e artigo $2^{\circ}$, a reserva de $20 \%$ das vagas em concursos públicos federais para as pessoas que se declarem de cor preta ou parda, dispensando, desta forma, o tratamento isonômico a um determinado grupo de indivíduos em função de critérios meramente biológicos: 
Art. $1^{\circ}$ Ficam reservadas aos negros $20 \%$ (vinte por cento) das vagas oferecidas nos concursos públicos para provimento de cargos efetivos e empregos públicos no âmbito da administração pública federal, das autarquias, das fundações públicas, das empresas públicas e das sociedades de economia mista controladas pela União, na forma desta Lei. [...]

Art. $2^{\circ}$ Poderão concorrer às vagas reservadas a candidatos negros aqueles que se autodeclararem pretos ou pardos no ato da inscrição no concurso público, conforme o quesito cor ou raça utilizado pela Fundação Instituto Brasileiro de Geografia e Estatística - IBGE. (BRASIL, 2014, paginação irregular)

Sob uma perspectiva superficial, a Lei 12.990 colide frontalmente com o tratamento isonômico referenciado na Constituição Federal. Complexa, todavia, é a tarefa de auferir um significado pertinente ao termo "igualdade", pairando sobre ele profundo subjetivismo. Desta forma, sua interpretação se dá de diferentes maneiras pelos membros da sociedade, juristas e doutrinadores. Consequentemente, a Impessoalidade na Administração Pública assume também diversas denominações: "O princípio em causa não é senão o próprio princípio da igualdade ou isonomia" (MELLO, 2011, p. 114). Nessa lógica, é importante evidenciar os múltiplos sentidos atribuídos ao referido princípio, uma vez que este que possui conteúdo jurídico geral. Portanto, dele é possível extrair distintos significados, dentre os quais vale destacar:

a) impessoalidade no sentido de isonomia: neste caso, a impessoalidade é interpretada como princípio da isonomia ou igualdade. Desta forma, teria por objetivo precípuo a vedação de qualquer tratamento discriminatório, que não contemple critérios de razoabilidade, impossibilitando a Administração pública de dispensar 
tratamento privilegiado ou prejudicial a particulares que se encontrem em situação equivalente;

b) impessoalidade no sentido de imparcialidade: exige que a Administração Pública adote instrumentos transparentes e objetivos no exercício da função administrativa, de modo a manter-se neutra e imparcial em suas decisões;

c) impessoalidade no sentido de finalidade: obriga a administração pública a pautar seus atos fundamentando-se no interesse público [...] (MAFFINI, 2016, p. 45).

Ao aprofundarmos a questão ampliando o significado atribuído ao termo podemos verificar que "A questão da igualdade está intrinsecamente correlacionada aos ideais de equidade e justiça" (MELLO; MOREIRA, 2015, p. 273). Nesse sentido é imprescindível que se faça a distinção entre a igualdade formal e a Igualdade material. Na primeira é atribuído o significado de mera isonomia perante a lei, ou seja, disposta apenas no papel. Já a segunda consiste na materialização desta isonomia já formalizada. Assim ela ganha efetivação por meio de ações que contemplem a justiça social e a dignidade da pessoa humana, superando, desta forma, o plano formal e assumindo o plano existencial. Por conseguinte, legitima a criação de ações afirmativas em decorrência da busca contínua pela justiça social (MELLO; MOREIRA, 2015, p. 273).

Assim, podemos afirmar que, em relação a isonomia disposta no caput do artigo 5ํㅜㄹ da Constituição Federal, esta não deve ser interpretada de maneira a obstaculizar a satisfação do interesse público pela Administração:

Essa igualdade não é de natureza material, mas sim jurídico-formal, na medida em que a Administração Pública, logicamente, não pode assegurar a igualdade de meios materiais a todos os administrados, 
mas pode, por seu turno assegurar a igualdade de oportunidades.

Assim, o princípio da igualdade ou isonomia não pode ser tomado em sentido totalmente absoluto, sob pena de transformar-se em empecilho à Administração Pública no atendimento do interesse público. (GOMES, 2006, p. 14)

Portanto, conclui-se que o princípio da igualdade não se esgota em sentido estrito, em realidade, tal direito fundamental veda arbitrariedades por parte do Estado quando determina tratamento isonômico para todos os cidadãos perante a lei. Deste modo, presume-se que o direito a igualdade não é absoluto, por quanto o mesmo comporta exceções, permitindo o tratamento desigual quando devidamente justificado e previsto em lei. Por conseguinte, a normativa atende ao disposto no artigo $5^{\circ}$, inciso II, da Constituição Federal, que assim determina: "ninguém será obrigado a fazer ou deixar de fazer alguma coisa senão em virtude de lei; " (BRASIL, 1988, paginação irregular). Já, no que se refere a interpretação atribuída a norma em Direito Administrativo, é importante ressaltar o seguinte:

Em Direito Administrativo, entretanto, a hermenêutica de maior valia será sempre a que prestigia, de modo particular, a prelazia axiológica e finalística contida em seus princípios, [...], desde os inafastáveis princípios fundamentais, destacando-se do elenco o princípio da finalidade, que contém a chave interpretativa para o bom entendimento da norma no Direito Administrativo, orientando adequadamente o aplicador para a satisfação do interesse público. (MOREIRA NETO, 2014, p. 121)

Dessa lição se absorve, portanto, a ideia de que o Direito Administrativo deve atender primordialmente a satisfação do interesse público e que a interpretação mais adequada a seus 
princípios é a finalística, ou seja, aquela que busca alcançar os fins precípuos da norma. Neste contexto:

A edição de uma lei não é um fenômeno ao acaso. Tudo aquilo que se faz no Parlamento, faz-se com vistas a um resultado pragmático, uma consequência no plano social. 0 texto legal é apenas uma referência para o intérprete que deve encontrar em seu enunciado a razão prática que originou a elaboração legislativa. Caso a interpretação da lei não alcance esse fim, então o Direito será ineficaz. (MAZZOTI, 2010, p. 72)

Assim, em relação ao que tange o princípio da igualdade, é correto afirmar que apesar de este possuir alto grau de dubiedade comportando variadas interpretações, a hermenêutica mais adequada é aquela que atenda a consequência no plano social para qual foi designado o referido princípio pelo legislador.

No que se refere às consequências no plano social, a Lei Federal 12.990, sancionada em 2014, tem apresentado resultados satisfatórios, reduzindo a disparidade entre brancos e negros no serviço público federal.

Das 11.900 pessoas que se tornaram servidores federais desde 2015, 2.370 foram admitidas por meio das cotas raciais, de acordo com a Secretaria Nacional de Políticas de Promoção da Igualdade Racial, que é responsável pela avaliação anual Lei de Cotas [...]. (SENADO, 2017, paginação irregular)

Ademais, vale lembrar ainda a importância conferida as políticas afirmativas de cotas no sentido de minimizar as desigualdades entre brancos, negros e pardos em nosso país:

[...] defensores das ações afirmativas veem as cotas como medidas significativas, pois elas se traduzem em uma efetiva ação política de cunho estatal que 
visa constituir um novo pacto social, mas com recorte etnorracial, a fim de minimizar a enorme distância social e econômica que separa negros e brancos. (FONSECA; 2009 p.111)

Desse modo as ações afirmativa de reserva de vagas para negros e pardos em concursos públicos tem alcançado números expressivos, atingindo seu objetivo precípuo de redução de desigualdades existentes no âmbito da administração pública federal. Como consequência, acaba por refletir de maneira mais harmônica a realidade de distribuição étnica da população brasileira nas repartições estatais.

\subsection{JUSTIÇA E AS DISCRIMINAÇÕES LÍCITAS}

Esclarecidos os questionamentos acerca da consonância das políticas públicas de inclusão frente ao princípio da igualdade, resta-nos confrontar se tais medidas contemplam o ideal de justiça. Para isso é necessário que se faça uma investigação voltada a busca pela essência do significado do termo "justiça", e como ele deve ser aplicado no direito brasileiro. De maneira mais superficial podemos afirmar que a justiça consiste em um critério por meio do qual podemos diferenciar o que é justo do que é injusto. Entretanto, por se tratar de um termo dúbio, variadas teorias da justiça já foram sustentadas ao longo da história do pensamento jurídico. Tais teorias se diferem conforme a resposta dada a seguinte pergunta: qual é o fim último do direito? Em meio a diversas concepções, é possível destacar três grupos (BOBBIO, 2000, p. 115):

a) concepção de justiça como ordem: essa teoria revela como fim último do direito a paz social. Nesta linha de pensamento, o homem criou um ordenamento jurídico a fim de superar o estado de anarquia e de guerra em que viviam. Assim, o direito atinge a sua finalidade precípua 
quando, por meio de um poder central, declara normas coercitivas as quais todos devem submeter-se, consolidando, desta forma, uma ordem social. Esta teoria surgiu visando salvaguardar o direito fundamental à vida;

b) concepção de justiça como igualdade: esta é a concepção mais antiga e tradicional, segundo a qual a finalidade do direito, ou seja, das regras disciplinadoras da conduta do homem em sociedade, é garantir que tanto na relação entre indivíduos (justiça comutativa), quanto nas relações entre Estado e indivíduo (justiça distributiva), prevaleça o ideal de igualdade. Por esta teoria o direito assume o papel de dar solução as disparidades entre os homens, decorrentes tanto de desigualdades naturais, quanto de desigualdades sociais. Ou seja, para que um ordenamento jurídico seja considerado justo deve enfrentar estas disparidades, protegendo os pobres dos ricos, os fracos dos fortes, estipulando normas que garantam tratamento igualitário a todos, com base em critérios fundamentais. Aqui vale salientar a possibilidade de tais critérios basearem-se no trabalho, no mérito, na necessidade etc. Assim, conforme esta teoria não basta a imposição pelo direito de uma ordem qualquer, uma vez que para que esta seja considerada justa deve pautar-se no respeito ao princípio da igualdade;

c) concepção de justiça como liberdade: conforme esta interpretação o direito tem por fim último a liberdade. Neste diapasão, foi com o intuito de garantir a expressão máxima da própria personalidade que os homens constituíram um poder estatal e formaram uma sociedade, o que não seria possível caso não houvessem normas coercitivas que garantissem a cada indivíduo sua parcela de liberdade. Por conseguinte, a norma considerada justa é aquela que permite a todos os membros da sociedade 
a possibilidade de fruir de sua liberdade, sem qualquer embaraço, de maneira a desenvolver de forma singular a própria personalidade. Nesta concepção de justiça o direito se consolida como um conjunto de limites impostos às liberdades individuais, garantindo a cada indivíduo a segurança de não ser lesado no âmbito do que lhe é legítimo, até o momento em que este não afete a esfera do que é lícito a terceiros. Assim, de acordo com esta concepção, não basta que a norma estabeleça uma ordem, tampouco que essa ordem seja pautada na igualdade. Para irradiar a luz da justiça é necessário que todos possam fruir de ampla liberdade. Logo, o ordenamento jurídico justo é aquele que estabelece ordem na liberdade (BOBBIO, 2000, p.116-118).

Neste contexto, a hermenêutica e o estudo sobre o verdadeiro significado de determinadas palavras desponta quando surge a necessidade de definir termos carregados de sentido emotivo, assim como é o termo "justiça". Ao reconhecer-lhes um significado, sua conclusão determina um certo acordo de valores. $\mathrm{Na}$ tentativa de fazer valer uma definição individual destes termos com sentido emotivo, o sujeito acaba por impor sua concepção de mundo, seu entendimento do que é justo ou injusto. Consequentemente, cada qual definirá à sua maneira tais conceitos indeterminados e carregados de valores (PERELMAN, 1996, p. 6). Ou seja, para que possamos atribuir um sentido conceitual a este tipo de palavra é imprescindível que seja reduzido o seu papel afetivo, desta forma tal noção superará o campo filosófico, admitindo o campo científico, este desprovido de paixão e fundamentado na lógica racional (PERELMAN, 1996, p. 7)

Para muitos a justiça é considerada como a principal virtude, matriz de todas as outras (PERELMAN, 1996, p. 7). Assim, as concepções do que é justo ou não em uma sociedade são, em 
geral, muito individualistas. Todas as revoluções, guerras e revoltas conhecidas atualmente se fizeram em nome da justiça. $\mathrm{Ou}$ seja, cada interessado sustenta uma definição do que lhe é justo, presumindo que a parte oposta sustenta, desta forma, o que é injusto. (PERELMAN, 1996, p. 8). Percebe-se, assim, que o termo possui uma incrível multiplicidade de sentidos, provocando verdadeira confusão em decorrência de seu uso. Portanto, é correto afirmar que a tentativa de elencar todos os sentidos possíveis da noção de justiça se mostra como uma tarefa utópica. Entretanto, é possível destacar as concepções mais recorrentes do referido termo (PERELMAN, 1996, p. 9):

a) a cada qual a mesma coisa: por essa concepção todos merecem tratamento igualitário, sem qualquer distinção. Assim, não se deve levar em consideração as particularidades de cada um, não importando se o indivíduo é jovem ou velho, rico ou pobre, doente ou saudável, bom ou mal, branco ou negro, culpado ou inocente. Justo é tratar todos da mesma forma. Segundo imaginário popular, perfeitamente justa é a morte, pois esta atinge a todos sem considerar qualquer privilégio;

b) a cada qual segundo seus méritos: tal concepção de justiça não contempla a igualdade de todos, porém, exige tratamento proporcional a uma qualidade intrínseca, o mérito de cada um. Questiona-se, entretanto, como definir esse mérito? Qual medida comum utilizar entre os méritos e deméritos de diferentes indivíduos? Quais critérios definirão o mérito? Em que medida levar em conta o resultado da ação, intenção ou sacrifício realizado? Neste caso, apenas tal valor intrínseco atribuído a cada indivíduo será o critério do julgador, cego a qualquer outra singularidade;

c) a cada qual segundo suas obras: este sentido de justiça não exige tratamento igual, mas sim tratamento propor- 
cional. Neste caso, porém, o critério não é moral, uma vez que não se vale da intenção ou sacrifícios realizados. Aqui o que se leva em consideração é unicamente o resultado da ação. Nesta forma de justiça os critérios utilizados para definir o que é justo são os elementos possíveis de ser calculados. Esta concepção admite muitas variantes, é por meio dela que se pautam os concursos, pois neles não se leva em conta o esforço que o candidato empenhou, apenas se considera o resultado alcançado;

d) a cada qual segundo suas necessidades: diferentemente das demais, essa fórmula de justiça não preocupa-se em avaliar os méritos do homem ou de sua produção. Seu objetivo é, sobretudo, reduzir os sofrimentos daqueles que, diante da impossibilidade em que se encontram, não conseguem satisfazer necessidades essenciais. Esta fórmula de justiça é a que se aproxima mais do que compreendemos por caridade. 0 que tal concepção leva em conta, portanto, é a garantia de assegurar um mínimo vital a cada sujeito. Foi por meio desta fórmula de justiça que a economia liberal foi contestada, uma vez que o trabalho (assimilado a mercadoria) ficava sujeito às mudanças do mercado, ou seja, da lei de oferta e procura. Assim, podemos afirmar que a tutela conferida ao trabalhador, salário mínimo, limitação de horas de serviço, seguro-desemprego, doença, o salário-família etc., foram inspirados neste tipo de justiça, a fim de assegurar a cada indivíduo a possibilidade de satisfazer suas demandas básicas;

e) a cada qual segundo sua posição: consiste em uma fórmula aristocrática de justiça, que não se importa em avaliar critérios intrínsecos ao sujeito, preocupa-se, entretanto, em rotular os seres conforme o seu perten- 
cimento ou não, a determinada categoria. Ou seja, não se aplicam as mesmas normas a todos, elas irão depender da categoria a que pertence o indivíduo. Assim, esta concepção não adota um sistema universalista, pois divide os homens em categorias. A título exemplificativo, podemos citar o tratamento diferenciado entre brancos e negros nas colônias, e entre oficiais e subordinados em âmbito militar. Tais distinções atingem a raça, a religião, a classe social e etc. Seu critério é, portanto, de natureza social, e na maioria das vezes hereditário, logo, independe da vontade do indivíduo. Desta forma, tal concepção de justiça é defendida de forma ferrenha por seus beneficiados, que exigem tratamento diferenciado quando em posições superiores;

f) a cada qual segundo o que a lei lhe atribui: segundo esta concepção, a justiça consiste na aplicação da lei. Por ela podemos afirmar que um juiz apenas será justo quando aplicar a idênticas situações, as mesmas leis. Vale salientar, porém, que cada legislação possui uma norma diferente, logo, por esta concepção a justiça é relativa de acordo com o ordenamento jurídico que a fundamenta (PERELMAN, 1996, p.9-12).

Por conseguinte, podemos deduzir que, assim como o termo "igualdade", alcançar um significado que reflita a essência da palavra "justiça" não se mostra como uma tarefa fácil, uma vez que todas as teorias trazem argumentos que apontam para algum tipo de racionalidade válida e presente em nossa sociedade.

Uma abordagem moral do tema em questão exige a resposta para a seguinte pergunta: "é injusto considerar raça e etnia fatores prioritários no mercado de trabalho e na admissão à universidade? ". Nesse sentido, destacam-se pelo menos três reflexões (SENDEL, 2015): 
a) a correção de distorções em testes padronizados: por este argumento, afirma-se que os exames de aptidão, da maneira como são aplicados, são incapazes de refletir a perspectiva de sucesso do sujeito. Nessa lógica, testes padronizados não são capazes de determinar o verdadeiro aproveitamento profissional ou acadêmico do indivíduo;

b) a compensação por erros do passado: a discriminação lícita, nesse caso, se justifica como uma solução que garante às minorias que as injustiças cometidas no passado, com consequências reflexas na atualidade, sejam remediadas, de modo a compensar a discriminação que os coloca em posição de inferioridade;

c) a promoção da diversidade: esse argumento não se funda na admissão do beneficiado como uma recompensa, mas sim como um meio de alcançar um objetivo socialmente mais relevante. Logo, a promoção da diversidade se dá em nome do bem comum. (SENDEL, 2015)

Tais considerações, entretanto, enfrentam duras críticas. No caso da compensação histórica entramos no campo da responsabilidade, uma vez que, em tese, a sociedade atual não teria qualquer obrigação de reparar os danos causados pela sociedade anterior. Nesse sentido, é temeroso ingressar na concepção de individualismo moral vez que, segundo este entendimento, nossas responsabilidades limitam-se apenas àquelas que por vontade própria assumimos. Desta forma, cada indivíduo é moralmente livre e independente de qualquer obrigação moral com a qual não tenha relação. Portanto, essa visão de liberdade restringe a responsabilidade coletiva, bem como o dever de arcar com as consequências morais de injustiças históricas cometidas, ainda que estas gerem efeitos na atualidade. Logo, esta noção acaba por afetar a forma como se aplica a justiça de modo mais geral. A ideia de liberdade presente no individualismo moral implica 
em dizer que os princípios de justiça em que se fundamentam os direitos não devem ser pautados por qualquer concepção moral. Pelo contrário, neste caso o direito deve assumir uma posição de neutralidade total diante da pluralidade de perspectivas presentes em uma sociedade. (SENDEL, 2015).

Entretanto, o individualismo moral não se aplica frente a questões de ordem coletiva, vez que é vedado aos Poderes Públicos que se mantenham inertes diante das desigualdades sociais. A busca pela justiça social se constitui como um verdadeiro dever do Estado, a quem compete tomar uma posição ativa diante da problemática, remetendo, desta forma, ao objeto das ações afirmativas empregadas aos vulneráveis diante de determinadas circunstâncias (MELLO; MOREIRA, 2017, p.277).

Assim, no que se refere a responsabilidade solidária dos membros de uma sociedade vale ressaltar a seguinte lição:

0 fato de pertencer a um determinado grupo nos torna, de certa forma, responsáveis. Não podemos ter orgulho de nosso país e de seu passado se não estivermos dispostos a assumir a responsabilidade de trazer sua história até os dias atuais, liberando-nos da dívida moral que possa vir com ela (SENDEL, 2015, paginação irregular)

Ademais, com relação as cotas, muitos ponderam sua aplicação alegando que justo seria que tal política afirmativa fosse voltada a contemplar o critério de classe social, e não racial como feito atualmente. Tal ponderação, todavia, não leva em consideração as barreiras discriminatórias suportadas pelos negros, nem o objetivo de reduzir distorções sociais entre a população negra e branca no Brasil.

O profissional negro, ainda que formado com excelência acadêmica, tem seu ingresso no mercado de trabalho, ou promoção, dificultado em decorrência de discriminações raciais. A cor de 
pele, nestes casos, prepondera sobre outros critérios seletivos. Logo, diante dos avanços já alcançados com as cotas étnico-raciais para ingresso no ensino superior, faz-se mister a discussão relativa ao ingresso de negros já capacitados no mercado de trabalho (GUIMARÃES, 2013).

Cumpre salientar ainda que a constitucionalidade das cotas raciais em concursos públicos já foi objeto de julgamento pelo Supremo Tribunal Federal, tendo como relator o Ministro Luís Roberto Barroso, que apontou como objetivos precípuos da norma o "dever de reparação histórica da escravidão e do racismo dela decorrente na sociedade brasileira. " (SENADO, 2017). Ou seja, as cotas não se justificam apenas pela compensação de injustiças do passado, mas também pela redução das desigualdades étnicoraciais presentes em nossa sociedade.

\section{OS NÚMEROS DA DESIGUALDADE}

Em 2014 o IPEA, Instituto de Pesquisa Econômica Aplicada, divulgou a nota técnica número 17 , apresentando a análise do Projeto de Lei 6738/2013, na qual são elucidadas algumas questões relativas a necessidade da reserva de vagas para negros e pardos em concursos públicos. De acordo com o referido estudo, os critérios universais fundados na meritocracia e na transparência não foram capazes de nivelar o quadro de negros e brancos no serviço público federal. As diferenças sociais e raciais persistem, fazendo-se necessária, portanto, a utilização de ações afirmativas capazes de promover a diversidade e representatividade dentro dos quadros públicos federais (SILVA T.; SILVA J., 2013, p. 3):

Na justificativa que acompanha o projeto, alega-se que, embora existam ganhos importantes em diversos campos sociais, persistem as desigualdades entre negros e brancos. Estas diferenças raciais se mantêm na composição dos cargos públicos da administração federal, ainda que ocupa- 
dos por meio de concursos públicos calcados na meritocracia e na transparência. Ou seja, esses mecanismos pretensamente neutros, assim como nas políticas universais, ainda não conseguiram reverter este quadro, justificando a necessidade de ações afirmativas. Destacam os benefícios da promoção da diversidade entre os servidores e o efeito demonstrativo que a medida tende a exercer para os setores público e privado. Consideram que estas cotas, somadas às melhorias promovidas por outras ações afirmativas, venham a aumentar a representatividade dos negros nos quadros públicos federais (SILVA, T., SILVA, J., 2013, p. 3)

Neste sentido, a tabela abaixo mostra a distribuição por cor ou raça de servidores públicos que ingressaram de 2007 a 2012 em determinadas ocupações do setor público federal, os dados foram disponibilizados pelo Sistema Integrado de Administração de Recursos Humanos (SIAPE):

Tabela - Raça/cor dos servidores que ingressaram no serviço público federal por grupo - cargo de 2007 - 2012 (Continua)

\begin{tabular}{lcc}
\hline Grupo - Cargo & $\begin{array}{c}\text { Branca e } \\
\text { Outras } 1 \\
\text { (\%) }\end{array}$ & $\begin{array}{c}\text { Negros e Par- } \\
\text { dos (\%) }\end{array}$ \\
\hline Diplomacia & 94,1 & 5,9 \\
Cargos da CVM/SUSEP - superior & 93,8 & 6,3 \\
Carreira de desenvolvimento tecnoló- & 90,7 & 9,3 \\
gico - superior & & \\
Carreira de pesquisa e desenvolvi- & 90,2 & 9,8 \\
mento em metrologia e qualidade & & \\
Auditoria da Receita Federal & 87,7 & 12,3 \\
Carreira de oficial de chancelaria & 86,7 & 13,3 \\
Carreira de procurador da Fazenda & 85,8 & 14,2 \\
Nacional & & \\
\hline
\end{tabular}


Tabela - Raça/cor dos servidores que ingressaram no serviço público federal por grupo - cargo de 2007 - 2012 (Conclusão)

Grupo - Cargo
Branca e Negros e Outras (\%) Pardos (\%)

Carreira fiscal do trabalho 83,4 16,6

Carreira na Defensoria Pública 80,5 19,5

Carreira de desenvolvimento tecno76,3 23,7 lógico - intermediário

Carreira da prev. da saúde e do 64,2 35,8 trabalho - intermediário

Carreira de perito federal agrário

- Incra

Especialista em meio ambiente

62,1

Plano geral de cargos Poder Execu-

38,8 tivo - nível intermediário

Carreiras de suporte técnico - vá38,8 rios órgãos - intermediário

Carreira do DNPM - intermediário 60,0 40,0

Carreira de reforma e desenho 58,3

agrário - Incra

Plano especial de cargos da cultura 56,3

- intermediário

Advocacia Geral da União (AGU) -

85,0

15,0 carreira da área jurídica

Cargos das agências reguladoras 84,4 15,6 superior

Fonte: SIAPE governo federal. Dados obtidos da Nota Técnica no 17, IPEA, 2014. Notas:

*Inclui raça/cor branca, amarela e indígena 
Desta forma conclui-se que a presença da população negra é ínfima em carreiras mais valorizadas, sobretudo naquelas que exigem nível superior e que, consequentemente, oferecem as melhores remunerações. Já em carreiras de nível médio aumenta o número de servidores públicos federais de cor negra. (SILVA, T., SILVA, J., 2013, p. 9). Segundo a referida análise, as desigualdades no campo educacional se refletem em outras esferas da vida social, atingindo inclusive o mundo do trabalho. Desta maneira, neste campo, os negros aparecem representados entre os desempregados, ou em posições desprotegidas e precárias. Vale salientar que mesmo que a questão da escolaridade seja equânime, via de regra, a população negra segue em desvantagem em relação as demais. (SILVA, T., SILVA, J., 2013, p. 4).

Esta diferença explica-se pelo fato de que a segregação racial nos papéis relativos às carreiras, posição na ocupação, setor de atividade e nível hierárquico reflete-se na desigualdade salarial entre negros e brancos, mesmo entre aqueles com igual nível de escolaridade. Ademais, o racismo produz e reproduz estas diferenças e atua de forma direta neste quadro (SILVA,T., SILVA, J., 2013, p. 5).

Vale salientar ainda o disposto na síntese de indicadores sociais, divulgada pelo IBGE em 2017. Segundo os estudos publicados pelo Instituto, as taxas de desocupação, ou desemprego, da população preta ou parda foram superiores às da população branca em todos os níveis de instrução (IBGE, 2017). Em que pese tais discrepâncias diminuam conforme aumenta o nível de escolaridade, ainda assim, considerando apenas o maior nível de instrução, há uma diferença de cerca de $20 \%$ na taxa de desocupação entre brancos, negros e pardos (IBGE, 2017). 
Gráfico 1 - Taxa de desocupação das pessoas de 16 anos ou mais de idade, por cor ou raça, segundo os néveis de instrução - Brasil - 2016

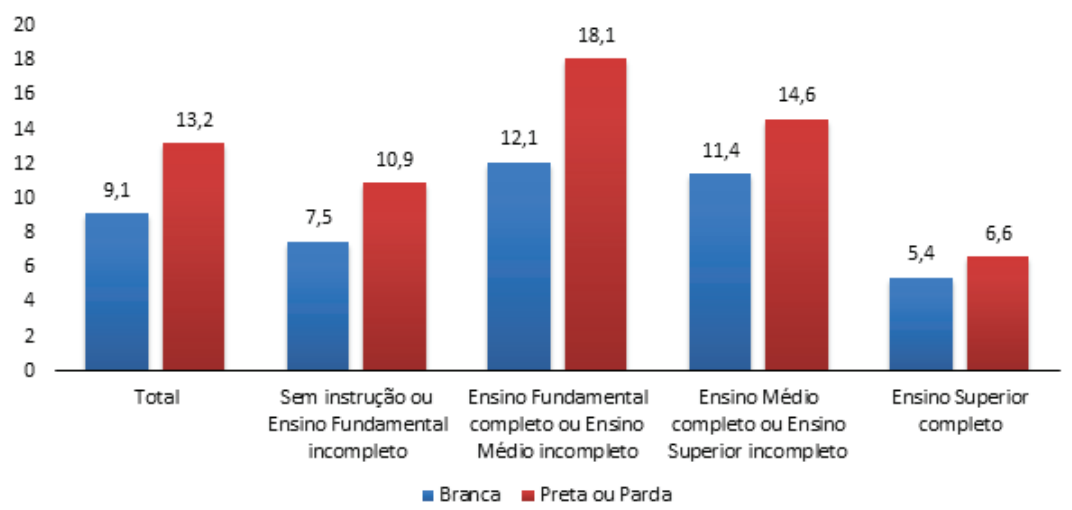

Fonte: IBGE, Pesquisa Nacional por Amostra de Domicílios Contínua, 2016 Dados obtidos da Síntese de Indicadores Sociais, IBGE, 2017

Ademais, podemos extrair do censo demográfico de 2010 disponibilizado pelo IBGE, Instituto Brasileiro de Geografia e Estatística, que as desigualdades sociais se refletem também no valor do rendimento médio mensal do brasileiro:

Gráfico 2 - Valor do rendimento médio mensal por cor ou raça, 2010

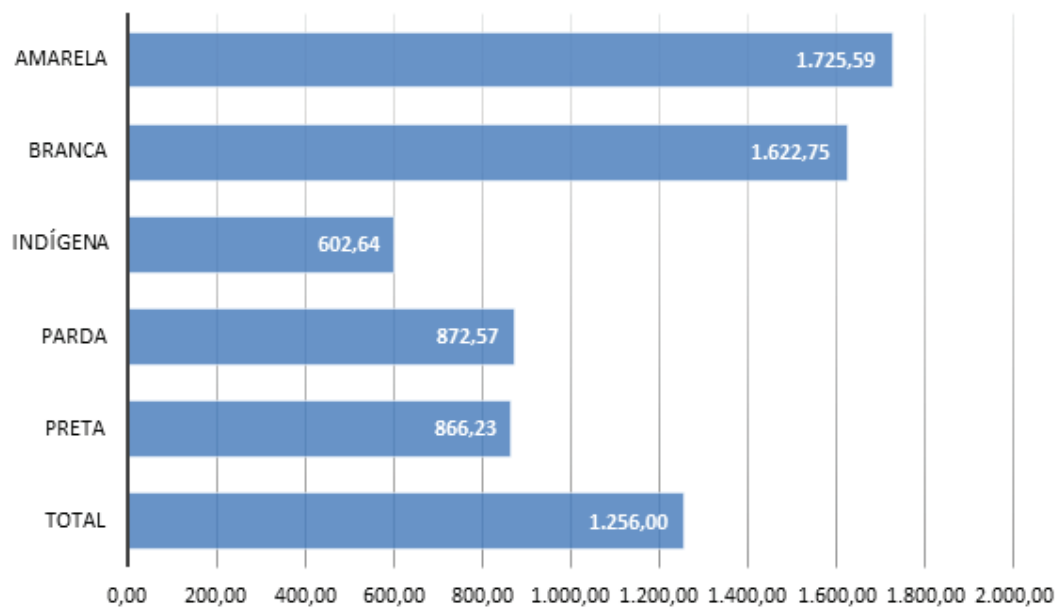

Fonte: IBGE, Censo Demográfico 2010 
Desta forma, podemos afirmar que as desigualdades sociais, o preconceito e o racismo atuam de forma determinante na construção dos quadros sociais brasileiros, afetando direta e indiretamente a população negra do Brasil.

\section{A CONSTITUCIONALIDADE DAS COTAS ÉTNICO-RA- CIAIS EM CONCURSOS PÚBLICOS NA PERSPECTIVA DO SUPREMO TRIBUNAL FEDERAL}

A questão da constitucionalidade das cotas étnico-raciais foi discutida por meio da Ação Declaratória de Constitucionalidade (ADC) 41, que teve seu julgamento concluído em junho de 2017 pelo plenário do Supremo Tribunal Federal. A ação afirmativa foi promovida pela lei $12.990 / 2014$, que estabelece a reserva de $20 \%$ das vagas ofertadas em concursos para o provimento de cargos efetivos e empregos públicos, na administração pública federal direta e indireta, no âmbito dos Três Poderes.

A decisão pela constitucionalidade da norma foi unânime, e teve como relator o Ministro Luís Roberto Barroso, que fundamentou sua decisão, entre outros motivos, no dever de reparação histórica, decorrente da escravidão e do racismo estrutural existente na sociedade brasileira. Os demais relatores, Alexandre de Moraes, Edson Fachin, Rosa Weber e Luiz Fux, acompanharam o relator (STF, 2017):

Origem: DISTRITO FEDERAL Entrada no STF: 26/01/2016 Distribuído: 27/01/2016 Relator: MINISTRO ROBERTO BARROSO Partes: REQUERENTE(S): CONSELHO FEDERAL DA ORDEM DOS ADVOGADOS DO BRASIL - CFOAB (CF 103, VII) INTERRESSADO (A/S): PRESIDENTE DA REPÚBLICA, CONGRESSO NACIONAL.

Ementa: DIREITO CONSTITUCIONAL. AÇÃO DIRETA DE CONSTITUCIONALIDADE. RESERVA DE VAGAS PARA NEGROS EM CONCURSOS PÚBLICOS. CONSTITUCIONALIDADE DA LEI N. 12.990/2014. PROCEDÊNCIA DO PEDIDO. 1. É 
constitucional a Lei n. 12.990/2014, que reserva a pessoas negras $20 \%$ das vagas oferecidas nos concursos públicos para provimento de cargos efetivos e empregos públicos no âmbito da administração pública federal direta e indireta, por três fundamentos. 1.1. Em primeiro lugar, a desequiparação promovida pela política de ação afirmativa em questão está em consonância com o princípio da isonomia. Ela se funda na necessidade de superar o racismo estrutural e institucional ainda existente na sociedade brasileira, e garantir a igualdade material entre os cidadãos, por meio da distribuição mais equitativa de bens sociais e da promoção do reconhecimento da população afrodescendente. 1.2. Em segundo lugar, não há violação aos princípios do concurso público e da eficiência. A reserva de vagas para negros não os isenta da aprovação no concurso público. Como qualquer outro candidato, o beneficiário da política deve alcançar a nota necessária para que seja considerado apto a exercer, de forma adequada e eficiente, o cargo em questão. Além disso, a incorporação do fator "raça" como critério de seleção, ao invés de afetar o princípio da eficiência, contribui para sua realização em maior extensão, criando uma "burocracia representativa", capaz de garantir que os pontos de vista e interesses de toda a população sejam considerados na tomada de decisões estatais. 1.3. Em terceiro lugar, a medida observa o princípio da proporcionalidade em sua tríplice dimensão. A existência de uma política de cotas para o acesso de negros à educação superior não torna a reserva de vagas nos quadros da administração pública desnecessária ou desproporcional em sentido estrito. Isso porque: (i) nem todos os cargos e empregos públicos exigem curso superior; (ii) ainda quando haja essa exigência, os beneficiários da ação afirmativa no serviço público podem não ter sido beneficiários das cotas nas universidades públicas; e (iii) mesmo que o concorrente tenha 
ingressado em curso de ensino superior por meio de cotas, há outros fatores que impedem os negros de competir em pé de igualdade nos concursos públicos, justificando a política de ação afirmativa instituída pela Lei $\mathrm{n}^{\circ}$ 12.990/2014. 2 . Ademais, a fim de garantir a efetividade da política em questão, também é constitucional a instituição de mecanismos para evitar fraudes pelos candidatos. É legítima a utilização, além da autodeclaração, de critérios subsidiários de heteroidentificação (e.g., a exigência de autodeclaração presencial perante a comissão do concurso), desde que respeitada a dignidade da pessoa humana e garantidos o contraditório e a ampla defesa. 3. Por fim, a administração pública deve atentar para os seguintes parâmetros: (i) os percentuais de reserva de vaga devem valer para todas as fases dos concursos; (ii) a reserva deve ser aplicada em todas as vagas oferecidas no concurso público (não apenas no edital de abertura); (iii) os concursos não podem fracionar as vagas de acordo com a especialização exigida para burlar a política de ação afirmativa, que só se aplica em concursos com mais de duas vagas; e (iv) a ordem classificatória obtida a partir da aplicação dos critérios de alternância e proporcionalidade na nomeação dos candidatos aprovados deve produzir efeitos durante toda a carreira funcional do beneficiário da reserva de vagas. 4. Procedência do pedido, para fins de declarar a integral constitucionalidade da Lei n. 12.990/2014. Tese de julgamento: "É constitucional a reserva de $20 \%$ das vagas oferecidas nos concursos públicos para provimento de cargos efetivos e empregos públicos no âmbito da administração pública direta e indireta. É legítima a utilização, além da autodeclaração, de critérios subsidiários de heteroidentificação, desde que respeitada a dignidade da pessoa humana e garantidos o contraditório e a ampla defesa". (ADC 41, Relator(a): Min. ROBERTO BARROSO, Tribunal 
Pleno, julgado em 08/06/2017, PROCESSO ELETRÔNICO DJe-180 DIVULG 16-08-2017 PUBLIC 17-08-2017)

Portanto, conclui-se que a mais alta instância do poder judiciário brasileiro pendeu para a constitucionalidade da norma por múltiplas razões. Verifica-se que a interpretação dada ao princípio da isonomia foi ampliada, não se restringindo a igualdade formal, pelo contrário, contemplou a busca pelo Poder Público da igualdade substancial, garantindo a população negra tratamento adaptado as mazelas a que são acometidos. Salienta-se ainda que a reserva de vagas para negros e pardos não fere os princípios norteadores dos concursos públicos, tampouco o princípio da eficiência, uma vez que a ação afirmativa não desonera o candidato da obrigação de atingir a nota necessária para que seja considerado apto a exercer o cargo. Além do mais, a pluralidade étnica no serviço público contribui para garantir uma melhor aplicação do princípio da eficiência, de modo a garantir que as decisões estatais sejam tomadas por profissionais que representem a diversidade do panorama social brasileiro, fortalecendo a relação de representatividade do Poder Público com o cidadão.

Desta forma, o princípio da proporcionalidade é observado em todos os seus aspectos quando aplicado às políticas públicas de inclusão. De modo que a existência de cotas para o acesso de negros ao curso superior não obsta a necessidade da ação afirmativa para o acesso destes na ocupação de cargos públicos. Isto se dá em razão de o curso superior não ser exigência em todos os cargos e empregos públicos, e ainda que fosse, o beneficiário da ação afirmativa não terá sido necessariamente beneficiado por cotas em universidades públicas. Por fim, é prudente lembrar que mesmo que o candidato tenha concluído o ensino superior por meio de cotas étnico-raciais, existem demais fatores que recaem sobre a população negra, impedindo-os de concorrer sob o prisma da igualdade formal com os demais candidatos, fundamentando, 
desta forma, a necessidade da aplicação da política afirmativa instituída pela Lei no 12990/2014 (STF, 2017).

\section{CONCLUSÃO}

Assim, elucidadas as questões que envolvem o presente artigo, podemos concluir que a reserva de vagas em concursos públicos para negros e pardos constitui medida assecuratória de direitos fundamentais, dado que a formação da sociedade brasileira, marcada por seu passado escravocrata, contribuiu de maneira essencial para a existência de desigualdades sociais entre brancos, negros e pardos.

Conforme exposto no presente artigo, por 350 anos o Estado e a sociedade foram coniventes com a escravidão de uma população inteira, promovendo a transformação do negro em mercadoria e lucrando com o sofrimento de vidas humanas. Foram três quartos de nossa história maculados por um sistema que se consolidou como a matriz de todas as desigualdades, gerando um abismo entre cores e classes. Consequentemente, hoje todos os brasileiros pagam um preço alto, uma vez que viver em uma sociedade desigual favorece a manutenção de fenômenos como a violência, a criminalidade, o desemprego, a má distribuição de renda, e tantos outros que impedem o desenvolvimento efetivo de uma nação. Desta forma, negar a esta população o direito a igualdade material é negar-lhes também a oportunidade de quebrar o círculo vicioso de discriminações e preconceitos que os atinge desde os primórdios de nossa história. É negar-lhes a reparação de um passado injusto e desumano que causou profundas cicatrizes na formação de nossa sociedade. Por fim, negar a esta população as mesmas oportunidades é negar à nação a construção de uma sociedade justa e igualitária.

Portanto, podemos deduzir que as ações afirmativas vêm como uma solução capaz de mitigar os efeitos reflexos de danos históricos e culturais sentidos contemporaneamente pelas po- 
pulações vulneráveis. Isto posto, podemos afirmar que a política de cotas guarda consonância com os ditames prescritos na atual Constituição Federal, que prima pela redução das desigualdades sociais como um de seus objetivos fundamentais. Assim, a interpretação dada ao princípio da igualdade na atual Carta Política foi esculpida em moldes extensivos e finalísticos, de maneira a abranger seus efeitos além da letra fria da lei, promovendo, desta forma, a igualdade substancial entre todos os cidadãos brasileiros. Logo, devemos encarar as cotas étnico-raciais como um importante passo na busca pela redução destes desequilíbrios sociais e, consequentemente, como um grande avanço ao desenvolvimento de nossa nação.

\section{REFERÊNCIAS BIBLIOGRÁFICAS}

AMARO, Sarita; Racismo, igualdade racial e políticas de ações afirmativas no Brasil [e-book]. Porto Alegre: Edipuc, 2015

BARROSO, Luís Roberto. Temas de direito constitucional. Rio de Janeiro: Renovar, 2002.

BOBBIO, Norberto; Direito e Estado no pensamento de Emanuel Kant [e-book] São Pulo: Mandarim, 2000

BRASIL, Constituição Federal da República Federativa do Brasil. Brasília: 1988. Disponível em:< http://www.planalto.gov.br/ccivil_03/ constituicao/constituicaocompilado.htm>. Acesso em: 04 Mai. 2018.

BRASIL, Lei Imperial n. 2040, de 28 de Setembro de 1871. Rio de Janeiro: 1871. Disponível em: < http://www.planalto.gov.br/ccivil_03/ leis/lim/LIM2040.htm >. Acesso em 08 Out. 2018.

BRASIL, Lei Imperial n. 3.353, de 13 de Maio de 1888. Rio de Janeiro: 1888. Disponível em: <http://www.planalto.gov.br/ccivil_03/leis/lim/ LIM3353.htm>. Acesso em 05 Mai. 2018.

BRASIL, Lei Imperial n. 3270, de 28 de Setembro de 1885. Rio de Janeiro: 1885. Disponível em: < http://www.planalto.gov.br/ccivil_03/ leis/lim/LIM2040.htm >. Acesso em 08 Out. 2018.

BRASIL, Lei Imperial n. 581, de 04 de Setembro de 1850. Rio de Janeiro: 1850. Disponível em: < http://www.planalto.gov.br/ccivil_03/ leis/lim/LIM581.htm >. Acesso em 08 Out. 2018. 
BRASIL. Supremo Tribunal Federal. ADC n. 41. Direito constitucional. Ação direta de constitucionalidade. Reserva de vagas para negros em concursos públicos. Constitucionalidade da lei n. 12.990/2014. Procedência do pedido. 2017. Disponível em < http://stf.jus.br/portal/ peticaoInicial/verPeticaoInicial.asp?base $=A D C N \& s 1=41 \&$ processo $=41$ $>$ Acesso em 20. Out. 2018.

BRRASIL. Lei Federal n. 12.990, de 09 de Junho de 2014. Brasília: 2014. Disponível em: <http://www.planalto.gov.br/ccivil_03/_ato20112014/2014/lei/l12990.htm> Acesso em: 07 Mai. 2018.

COSTA, Emília Viotti da. Da senzala à colônia. São Paulo: Fundação Editora da UNESP, 1998.

DOLHNIKOFF, Miriam. História do Brasil Império. São Paulo: Contexto, 2017.

DUQUE ESTRADA, Osório. A abolição. Brasília: Senado Federal, Conselho Editorial, 2005.

FAUSTO, Boris. História concisa do Brasil. São Paulo: Editora da Universidade de São Paulo, 2006.

FEDERAL, Senado. Notícias Senado. Senadores elogiam decisão do STF e diz que cotas para negros reparam injustiça, 2017, Disponível em: < https://www12.senado.leg.br/noticias/materias/2017/06/09/ senadores-elogiam-decisao-do-stf-e-diz-que-cotas-para-negros-reparam-injustica > Acesso em: 28 Out. 2018.

FEDERAL, SENADO. Portal de notícias; Lei de Cotas em concurso é julgada constitucional, mas ainda motiva ações. 2017. Disponível em < https://www12.senado.leg.br/noticias/especiais/especial-cidadania/ lei-de-cotas-em-concurso-e-julgada-constitucional-mas-ainda-motiva-acoes > Acesso em 04 Jun. 2018

FEDERAL, Supremo Tribunal. Notícias STF. Plenário declara constitucionalidade da Lei de Cotas no serviço público federal; 2017, Disponível em: < http://stf.jus.br/portal/cms/verNoticiaDetalhe. asp?idConteudo=346140 > Acesso em: 25 Out. 2018.

FELIPE, Delton Aparecido. A EDUCAÇÃo DA POPULAÇÃo NEGRA NA FORMAÇÃO DO ESTADO MODERNO BRASILEIRO. Revista da Associação Brasileira de Pesquisadores/as Negros/as (ABPN), [S.l.], v. 7, n. 17, p. 322-342, out. 2015. ISSN 2177-2770. Disponível em: <http://www. abpnrevista.org.br/revista/index.php/revistaabpn1/article/view/84>. Acesso em: 06 nov. 2018. 
FONSECA, Dagoberto José. Políticas Públicas e Ações Afirmativas. São Paulo: Selo Negro, 2009.

GOMES, Fábio Bellotte. Elementos de direito Administrativo. Barueri, SP: Manolle, 2006.

GUIMARÃES, Reinaldo da Silva; Afrocidadanização: ações afirmativas e trajetórias de vida no Rio de Janeiro [e-book]. Rio de Janeiro: Selo Negro, 2013.

HACK, Érico. Direito constitucional: conceitos, fundamentos e princípios básicos [livro eletrônico]. Curitiba: InterSaberes, 2012.

IBGE, Censo Demográfico 2010. 2010. Disponível em: < https://www. ibge.gov.br/estatisticas-novoportal/sociais/populacao/9662-censo- demografico $-2010 . h t m l$ edicao $=9752 \& \mathrm{t}=$ destaques $>$. Acesso em 29 Out. 2018.

IBGE, Síntese de indicadores sociais. 2017. Disponível em: < https:// biblioteca.ibge.gov.br/visualizacao/livros/liv101459.pdf >. Acesso em 29 Out. 2018.

LOBO, Andréa Maria Carneiro; Portella, José Roberto Braga. Percursos da história moderna [livro eletrônico]. Curitiba: InterSaberes, 2017. MACEDO, José Rivair. História da África. São Paulo: Contexto, 2013.

MAFFINI, Rafael. Elementos do Direito Administrativo: Atualizado até a lei 13.303/2016 - Estatuto das Estatais. Porto Alegre: Livraria do Advogado, 2016.

MARTINS, Ives Gandra da Silva. Conheça a Constituição: Comentários à Constituição Brasileira. Barueri, SP: Manole, 2005.

MARTINS, Rodrigo Perla; MACHADO, Carlos R. S. (org.). Identidades, movimentos e conceitos: fundamentos para a discussão da realidade brasileira. Novo Hamburgo: Feevale, 2004.

MATTOS, Regiane Augusto de. História e Cultura Afro-Brasileira. São Paulo: Contexto, 2007.

MAZZOTI, Marcelo. As escolas hermenêuticas e os métodos de interpretação da lei. Barueri, SP: Minha Editora, 2010.

MELLO, Celso Antônio Bandeira de. Curso de Direito Administrativo. São Paulo: Malheiros, 2011.

MELLO, Cleyson de Moraes; MOREIRA, Thiago. Direitos Fundamentais e Dignidade da Pessoa Humana. Rio de Janeiro: Freitas Bastos, 2015. 
MESGRAVIS, Laima. História do Brasil colônia. São Paulo: Contexto, 2015. MIRANDA, Shirley Aparecida de; Diversidade e ações afirmativas: combatendo as desigualdades sociais. Belo Horizonte: Autentica Editora, 2010

MoREIRA NETO, Diogo de Figueiredo. Curso de Direito Administrativo: parte introdutória, parte geral e parte especial. Rio de Janeiro: Forense, 2014.

OLIVEIRA, Sidney de Paula. 0 Estatuto da Igualdade Racial. São Paulo: Selo Negro, 2013.

PERELMAN, Chaïm; Ética e Direito [e-book]. São Paulo: Martins Fontes, 1996. PINSKY, Jaime. A Escravidão no Brasil. São Paulo: Contexto, 2010

PINTO JÚNIOR, Osmar; CARDOSO, Iara. Brasil: que raio de história. São Paulo: Oficina de Textos, 2015.

RIBEIRO, Darcy. 0 povo brasileiro: a formação e o sentido do Brasil. São Paulo: Companhia das Letras, 1995.

SANTOS, Gevanilda. Relações raciais e desigualdade no Brasil. São Paulo: Selo Negro, 2009.

SENDEL, Michael J.. Justiça, o que é fazer a coisa certa; tradução de Heloisa Matias e Maria Alice Máximo. [e-book]. - Rio de Janeiro: Civilização Brasileira, 2015.

SILVA, Tatiana Dias; SILVA, Josenilton Marques da. Reserva de vagas para negros em concursos públicos: uma análise a partir do Projeto de Lei 6.738/2013. 2014. Disponível em: < http://www.ipea.gov. $\mathrm{br} /$ portal/index.php?option=com_content\&view=article\&id=21377 > Acesso em 18 Set. 2018.

VISENTINI, Paulo Fagundes; RIBEIRO, Luiz Dario Teixeira; PEREIRA, Analúcia Danilevicz. História da África e dos africanos. Rio de Janeiro: Vozes, 2014.

VITA, Álvaro de. Sociologia da Sociedade Brasileira. São Paulo: Ática, 2004. 